\title{
Holocene record of large explosive eruptions from Chaitén and Michinmahuida Volcanoes, Chile
}

\author{
Álvaro Amigo ${ }^{1}$, Luis E. Lara ${ }^{1}$, Victoria C. Smith ${ }^{2}$ \\ ${ }^{1}$ Servicio Nacional de Geología y Minería, Programa de Riesgo Volcánico, Avda. Santa María 0104, Santiago, Chile. \\ alvaro.amigo@sernageomin.cl; luis.lara@sernageomin.cl \\ ${ }^{2}$ Research Laboratory for Archaeology and the History of Art, University of Oxford, U.K. \\ victoria.smith@rlaha.ox.ac.uk
}

\begin{abstract}
Tephra fall deposits and one large ignimbrite close to Chaitén and Michinmahuida Volcanoes were analyzed for chemistry and radiocarbon dated to correlate the eruptive units and establish the timing of eruptions. These data suggest that both volcanoes were the source of large $(\mathrm{VEI} \geq 5)$ and small to moderate $(\mathrm{VEI}<5)$ explosive eruptions throughout the Holocene. Four deposits are associated with volcanic activity from Chaitén Volcano, with two from Plinian eruptions at 9.9-9.5 and 5.3-4.9 (cal) ka BP that also generated pyroclastic density currents. The last event recognized from Chaitén (prior 2008) occurred a few hundred years ago, producing deposits that are similar to those of the 2008 eruption. All products from Chaitén are high-silica rhyolites; whole-rock compositions are indistinguishable but glass compositions are subtly different for some of the units. Seven deposits are related to eruptions of Michinmahuida Volcano, including a Plinian fall deposit at 7.6-7.3 ka BP and a large ignimbrite deposit at 10.5-10.2 ka BP. The chemical compositions of these products range from andesite to dacite. The last substantial explosive eruption event from Michinmahuida Volcano appears to have been a $0.5-0.3 \mathrm{ka}$ BP sub-Plinian eruption, although younger scoria fall deposits likely derived from local pyroclastic cones are also found. Both volcanoes pose a wide variety of potential hazards to the region ranging from those derived from ignimbrite-forming eruptions to pyroclastic-cone formation. Valleys adjacent to the volcanoes were the areas most heavily affected by volcanic activity, because they were inundated by pyroclastic density currents and lahars. However, even regions located tens of kilometers east and north of the volcanoes experienced accumulations of tephra, which could harm both agriculture and infrastructure if similar events occurred today.
\end{abstract}

Keywords: Tephra fall deposits, Tephrochronology, Explosive volcanism, Southern Volcanic Zone, Volcanic glass chemistry.

RESUMEN. Registro de erupciones explosivas holocenas de los volcanes Chaitén y Michinmahuida, Chile. En las cercanías de los volcanes Chaitén y Michinmahuida se han estudiado un conjunto de depósitos piroclásticos de caída y un depósito ignimbrítico. Estos se han caracterizado mediante análisis químico (de roca total y microsonda en vidrio volcánico) y datados por medio de isótopos de radiocarbono. De esta forma, se ha establecido una nueva cronología eruptiva para estos centros. Los datos obtenidos sugieren que ambos volcanes presentan conspicua actividad explosiva durante el Holoceno de variada magnitud. En particular, se han identificado depósitos de al menos cuatro erupciones asociadas al volcán Chaitén, incluyendo dos Plinianos ocurridas entre 9.9-9.5 y 5.3-4.9 ka antes del presente, que generaron, además, corrientes piroclásticas en los valles adyacentes. El evento más reciente identificado para este volcán, corresponde a una erupción de similar magnitud a la del 2008 y habría ocurrido unos tres siglos antes del presente. Para este volcán, todos sus productos piroclásticos corresponden a riolitas, cuyas composiciones de roca total resultan prácticamente indistinguibles, aunque análisis del vidrio volcánico muestra diferencias. Por otra parte, siete erupciones han sido identificadas para el volcán Michinmahuida, incluyendo un depósito ignimbrítico emplazado en el Holoceno temprano entre 10.5-10.2 ka antes del presente y una erupción Pliniana ocurrida entre de 7.6-7.3 ka antes del presente. Las composiciones de los piroclastos de este volcán varían desde andesitas a dacitas, y la últma erupción habría correspondido a una del tipo subpliniana ocurrida hace unos 500 años; no obstante, se han identificado depósitos más recientes probablemente derivados de la actividad de conos piroclásticos. En suma, ambos volcanes representan potencial peligro en la región, cuyas zonas más afectadas corresponderían a los valles adyacentes a los volcanes, ya sea por corrientes piroclásticas o lahares. Sin embargo, regiones distantes decenas de kilómetros, particularmente hacia el norte y este de los volcanes, han experimentado acumulaciones importantes de tefra, cuyos efectos serían devastadores si eventos de similar magnitud ocurrieran en el futuro. 


\section{Introduction}

Chaitén Volcano $\left(42.83^{\circ} \mathrm{S}, 72.65^{\circ} \mathrm{W}, 1,120 \mathrm{~m}\right.$ a.s.1.) and Michinmahuida Volcano $\left(42.79^{\circ} \mathrm{S}, 72.44^{\circ} \mathrm{W}\right.$, 2,405 $\mathrm{m}$ a.s.1.) are located in the southern segment of the Andean Southern Volcanic Zone (SVZ), which extends between Calbuco $\left(41.3^{\circ} \mathrm{S}\right)$ and Hudson $\left(45.9^{\circ} \mathrm{S}\right)$ Volcanoes (Stern, 2004). Unlike most of the volcanic centers located along the SVZ, these two volcanoes are separated by only $20 \mathrm{~km}$ in an east-west alignment, which is an unusual spatial configuration (Fig. 1). Michinmahuida is a large stratovolcano located atop the main trace of the Liquiñe-Ofqui Fault Zone (LOFZ), with an elongate NE-SW summit ridge and an ice-filled caldera in the upper part of the edifice. It is one the largest volcanoes located in the southernmost SVZ $\left(c a .165 \mathrm{~km}^{3}\right)$.
The composition reported for its volcanic products range from basaltic-andesite to dacite (e.g., Naranjo and Stern 2004; Kilian and López-Escobar, 1992; López-Escobar et al., 1993). In contrast, Chaitén Volcano is a small complex of rhyolitic domes of ca. $1 \mathrm{~km}^{3}$ after the 2008 eruption (Pallister et al., 2013, this volume), built inside of a caldera located west of the LOFZ. Detailed surveys of the stratigraphy and evolution of both volcanoes are not available, although reconnaissance investigations show that they differ significantly in terms of chemical signatures (Kilian and López-Escobar, 1992; Watt et al., 2013, this volume).

Chaitén Volcano erupted explosively in May 2008, raising the attention of the scientific community on this remote region of northern Patagonia (e.g., Folch et al., 2008; Carn et al., 2009; Watt et al., 2009).

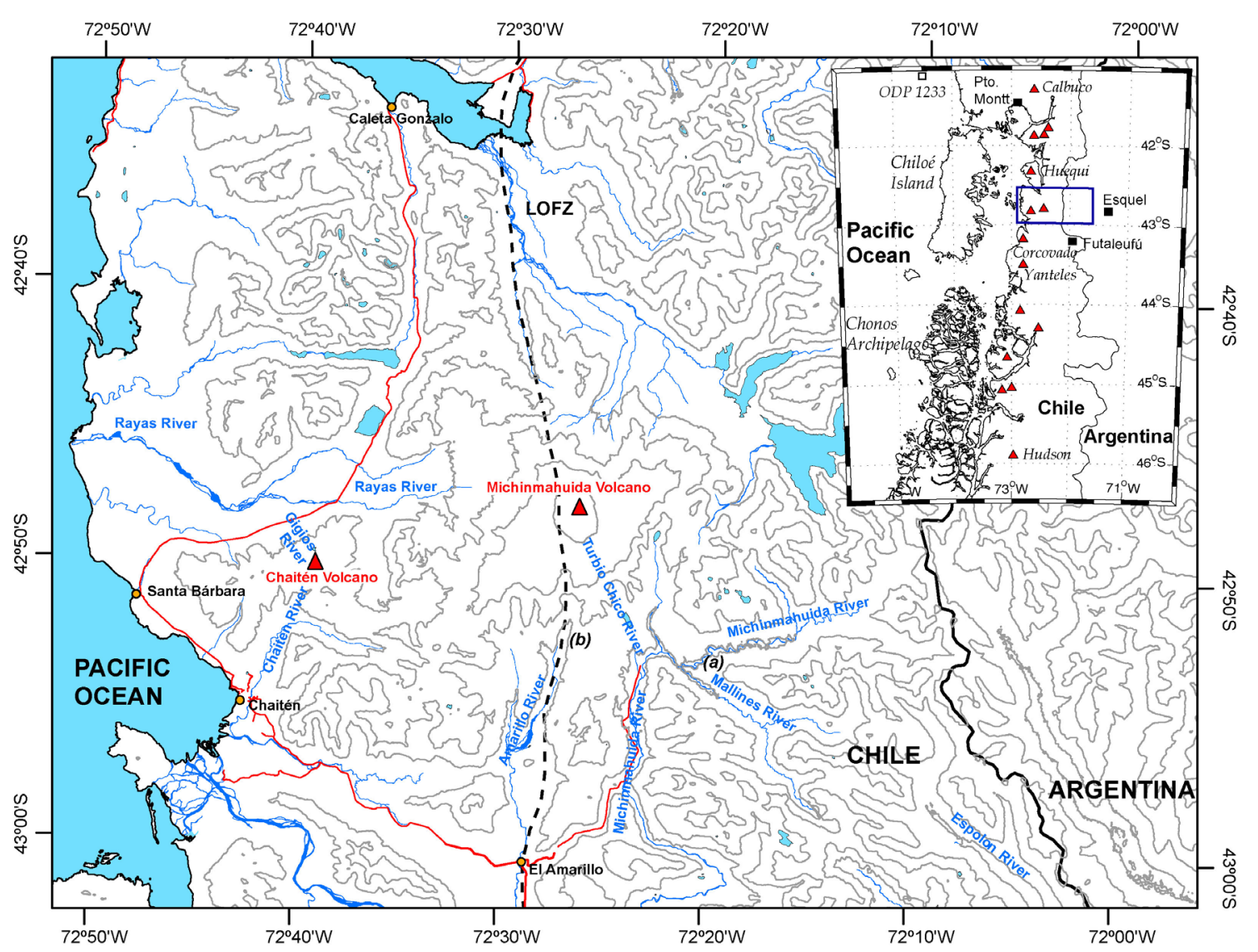

FIG. 1. Location map for Chaitén and Michinmahuida Volcanoes. Location of the Mallines section (a) and the upper southern flank of Michinmahuida Volcano (b) are indicated as well as the main trace of the Liquiñe-Ofqui Fault Zone (LOFZ) as a dashed line. Contour lines every $500 \mathrm{~m}$ a.s.l. are shown. The inset shows the location of the studied area in the southernmost SVZ context, main volcanoes and the ODP 1233 deep-sea core site. 
After two years of both explosive and effusive activity, about $1 \mathrm{~km}^{3}$ of dense rhyolitic magma was erupted (Alfano et al., 2011; Major and Lara, 2013, this volume; Pallister et al., 2013, this volume). That event is the only certain eruption during historical times, even though historical reports point to Chaitén Volcano as the source of an explosive eruption in the region during the $17^{\text {th }}$ century (Lara et al., 2013, this volume).

Previous studies suggest that after a large Plinian eruption in the early Holocene, Chaitén Volcano was dormant until 2008 (Naranjo and Stern, 2004). However, Watt et al. (2013, this volume) demonstrate that Chaitén erupted explosively again after the early Holocene paroxysmal event. In fact, based on a proximal pyroclastic sequence, they provide evidence for three mid- to late-Holocene eruptions.

We complement the study by Watt et al. (2013, this volume) by focusing our attention on large events from Chaitén and Michinmahuida Volcanoes. Our objective is to establish more complete chronologies of their large eruptive events. To get a complete view of these large events, special attention is paid to both very proximal sites, where complete exposures were found, and to distal outcrops where major eruptions still can be recognized. Here, we present stratigraphic correlations, chemistry (whole-rock and microprobe) and ${ }^{14} \mathrm{C}$ radiometric dates, which show that both volcanoes have been sites of large eruptions throughout the Holocene. Therefore, these volcanoes pose a significant threat to communities across the southern regions of Chile and Argentina.

\section{Methods}

The area around Chaitén and Michinmahuida Volcanoes is largely uninhabited, densely vegetated and has very few roads. Access was variably by 4-wheel-drive truck, horseback, walking and, in a couple of remote places, by helicopter. Samples were collected from $c a$. 50 sections around both volcanoes, mainly around the southern, northern and southeastern sides of the volcanoes; the northeastern part of the area remains unvisited.

\subsection{Whole-rock chemistry}

Several authors have used the distinctive compositions of pyroclasts derived from Chaitén and Michinmahuida in order to identify the sources of tephra deposits. These identifications are based mostly on the rhyolitic composition of Chaitén, because it is the only Holocene source of rhyolite in the southern part of the SVZ. We conducted major- and trace-element analyses for 12 whole-rock samples from Michinmahuida and 3 whole-rock samples from Chaitén (Table 1). Pyroclastic samples were first crushed to less than $0.074 \mathrm{~mm}$ and then compositional analyses were done at the Servicio Nacional de Geología y Minería (SERNAGEOMIN) laboratory by X-Ray fluorescence (XRF) for major elements, and by inductively coupled plasma mass spectrometry (ICP-MS) for trace and rare-earth elements. Relative errors in measurements are usually less than $0.5 \%$ for major elements and less than $3 \%$ for trace elements.

Semi-quantitative analysis of mineral content was obtained through X-ray diffraction (XRD) analyses at the SERNAGEOMIN's laboratory on a Panalytical XPert PRO diffractometer, for a $5^{\circ}-65^{\circ} 2 \mathrm{q}$ scan at $0.02^{\circ}$ every 5 seconds. Bulk samples were previously powdered to $0.074 \mathrm{~mm}$ using an agate mortar.

\subsection{Glass chemistry}

Glass shards from 6 samples from Chaitén, 3 samples from Michinmahuida and 1 ash sample from a deep sea core (ODP 1233 site) were analyzed (Table 2). Pumice lapilli were lightly crushed, wet sieved, and dried in an oven at $60^{\circ} \mathrm{C}$. Glass shards were selected and then mounted in epoxy resin blocks and polished for analysis. More than 300 individual glass shards were analyzed using a wavelength-dispersive electron microprobe at the Research Laboratory for Archaeology and the History of Art, University of Oxford. An accelerating voltage of $15 \mathrm{kV}$, beam current of $6 \mathrm{nA}$, and defocussed ( $\sim 10$ micron diameter) beam were used. Peak counting times were $30 \mathrm{~s}$ for $\mathrm{Si}, \mathrm{Al}, \mathrm{Fe}, \mathrm{Ca}, \mathrm{K}, \mathrm{Ti} ; 40 \mathrm{~s}$ for $\mathrm{Cl}$ and $\mathrm{Mn} ; 60 \mathrm{~s}$ for $\mathrm{P}$, and $10 \mathrm{~s}$ for $\mathrm{Na}$. The electron microprobe was calibrated using a suite of mineral standards, and the PAP absorption correction method was used for quantification. Accuracy of the electron microprobe analyses was assessed using a suite of secondary glass standards (MPI-DING glasses; Jochum et al., 2006). During all runs the secondary standards were within 2 standard deviations of the preferred values (see Jochum et al., 2006). Analytical errors associated with the concentrations are: $<0.3 \%$ relative standard deviation for $\mathrm{Si}, 1 \%$ for $\mathrm{Al}, 3 \% \mathrm{Ca}, \mathrm{K}$, and $\mathrm{Na}, 7 \%$ 
TABLE 1. WHOLE-ROCK MAJOR AND TRACE ELEMENT COMPOSITIONS DETERMINED BY XRF AND ICP-MS.

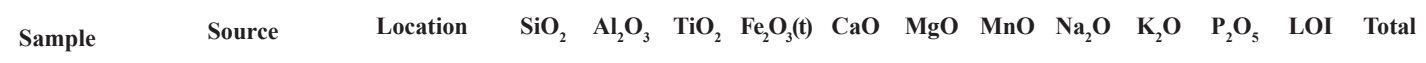
wiching Amarillo ignim-
brite at Turbio

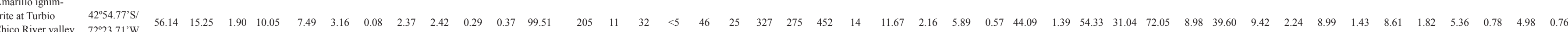
(bomb)

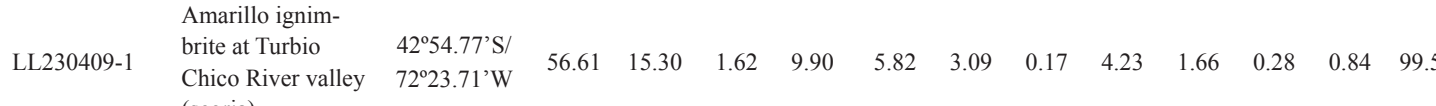

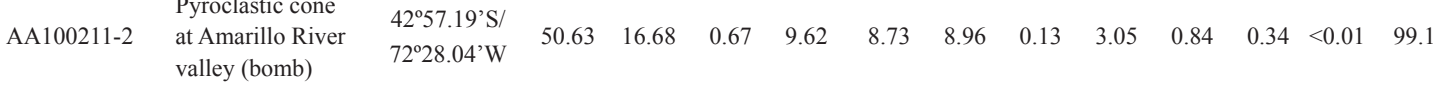

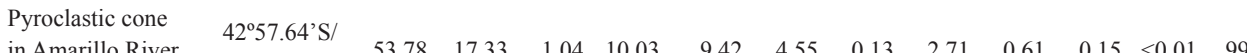
in Amarillo River
valley (csoria)

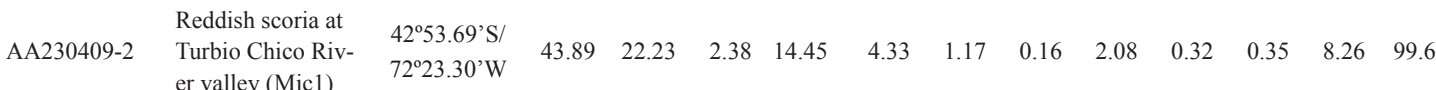

Grey pumice at
Turbio Chico Ri-

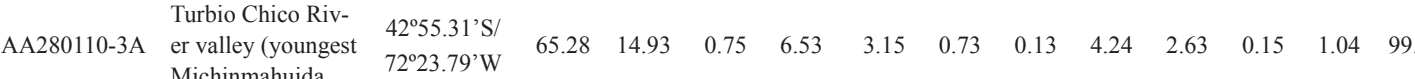
Michinmahuida $72^{223.79}$

AA040311-1C $\begin{aligned} & \text { Mallines sect } \\ & \left(1^{*} \text { scoria) }\right.\end{aligned}$ $\begin{array}{llllllllllllll}42^{2} 53.30^{\circ} \mathrm{S} / \mathrm{W} & 51.37 & 14.43 & 1.98 & 15.08 & 8.18 & 2.18 & 0.13 & 3.97 & 1.50 & 0.37 & 0.71 & 99 & \end{array}$

AA040311-1D $\begin{array}{llllllllllllll}\text { Mallines section } & 42^{2533.30^{\circ} \mathrm{S} /} & 50.26 & 14.77 & 1.98 & 14.91 & 7.42 & 2.85 & 0.14 & 3.80 & 1.56 & 0.40 & 1.56 & 99.65\end{array}$

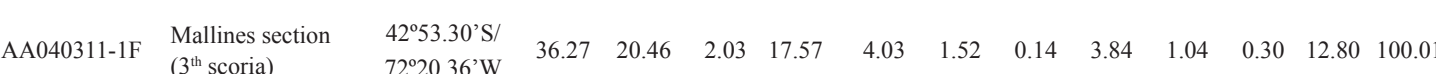

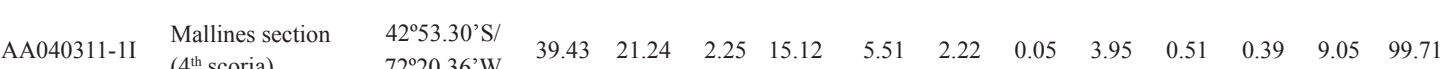
AA040311-10 $\begin{array}{llllllllllllll}\text { Mallines section } & 42^{\circ} 53.30^{\circ} \mathrm{S} / & 48.21 & 22.58 & 1.33 & 8.18 & 3.64 & 1.34 & 0.05 & 3.83 & 0.86 & 0.22 & 9.35 & 99.58\end{array}$

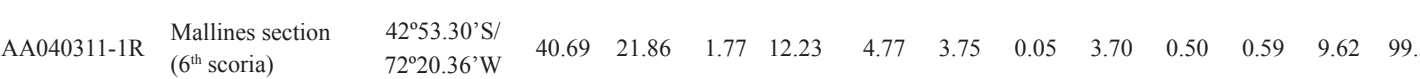

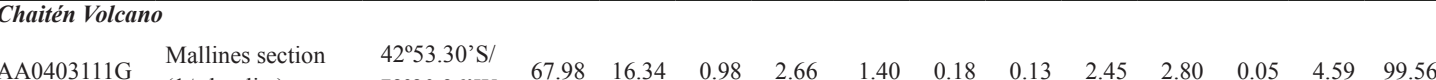

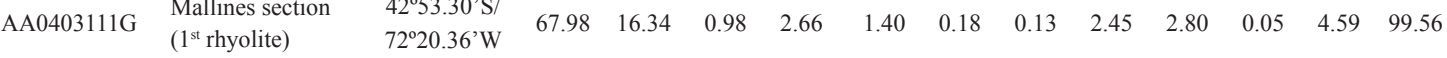

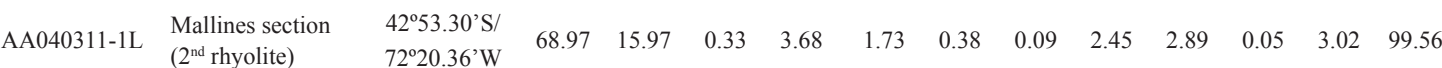

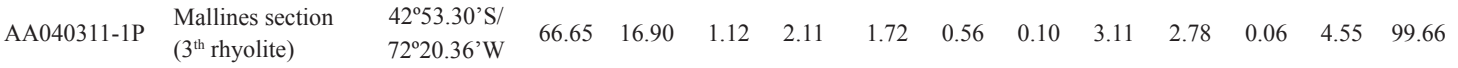

$\begin{array}{lllllllllllllllllllllllllllllll}<10 & <10 & <5 & <5 & 21 & 56 & 108 & 74 & 560 & 18 & 7.49 & 5.95 & 2.53 & 0.70 & 54.60 & 3.11 & 15.88 & 32.24 & 56.38 & 5.77 & 19.47 & 3.32 & 0.68 & 2.83 & 0.37 & 2.19 & 0.46 & 1.31 & 0.19 & 1.32 & 0.20\end{array}$

$\begin{array}{lllllllllllllllllllllllllllllll}256 & 13 & 37 & <5 & 42 & 19 & 332 & 194 & 368 & 12 & 9.70 & 1.65 & 4.96 & 0.49 & 20.05 & 1.11 & 47.06 & 26.06 & 60.43 & 7.66 & 34.45 & 8.18 & 2.13 & 7.91 & 1.22 & 7.48 & 1.64 & 4.45 & 0.62 & 4.07 & 0.60\end{array}$ $\begin{array}{llllllllllllllllllllllllllllllll}204 & 10 & 68 & 6 & 101 & 39 & 296 & 206 & 355 & 11 & 10.09 & 1.82 & 5.31 & 0.53 & 24.75 & 1.37 & 56.46 & 30.39 & 72.58 & 8.91 & 39.73 & 9.38 & 2.42 & 8.87 & 1.38 & 8.37 & 1.77 & 4.84 & 0.68 & 4.45 & 0.68\end{array}$ $\begin{array}{llllllllllllllllllllllllllllllll}214 & 10 & 52 & <5 & 31 & 18 & 190 & 209 & 216 & 17 & 9.79 & 0.92 & 5.42 & 0.54 & 25.46 & 1.50 & 61.08 & 35.45 & 72.17 & 9.26 & 42.13 & 9.86 & 2.52 & 9.44 & 1.50 & 9.02 & 2.00 & 5.37 & 0.75 & 4.78 & 0.71\end{array}$ $\begin{array}{lllllllllllllllllllllllllllllll}343 & 19 & 55 & <5 & 15 & 11 & 306 & 158 & 110 & 10 & 6.62 & 0.19 & 3.80 & 0.29 & 29.83 & 0.85 & 36.78 & 22.50 & 46.92 & 6.85 & 29.96 & 7.16 & 2.03 & 6.60 & 1.02 & 6.17 & 1.31 & 3.55 & 0.47 & 3.25 & 0.46\end{array}$ $\begin{array}{llllllllllllllllllllllllllllllll}94 & 13 & 34 & <5 & 34 & 18 & 197 & 175 & 235 & 13 & 5.88 & 1.16 & 4.32 & 0.29 & 34.32 & 0.93 & 36.15 & 22.84 & 46.73 & 6.10 & 26.13 & 6.19 & 1.68 & 5.53 & 0.91 & 5.57 & 1.17 & 3.39 & 0.51 & 3.21 & 0.51\end{array}$ $\begin{array}{lllllllllllllllllllllllllllllll}185 & 128 & 51 & 12 & 16 & 12 & 212 & 221 & 121 & 11 & 10.39 & 0.18 & 5.01 & 0.51 & 35.53 & 0.85 & 43.04 & 30.39 & 62.09 & 9.41 & 41.38 & 9.42 & 2.18 & 8.37 & 1.30 & 7.61 & 1.54 & 4.56 & 0.65 & 4.02 & 0.61\end{array}$ $\begin{array}{lllllllllllllllllllllllllllllll}14 & <10 & <5 & <5 & 28 & 56 & 137 & 82 & 570 & 19 & 7.84 & 6.58 & 2.45 & 0.71 & 91.20 & 2.96 & 18.47 & 31.78 & 57.01 & 6.04 & 20.95 & 3.58 & 0.75 & 2.96 & 0.44 & 2.44 & 0.51 & 1.52 & 0.24 & 1.54 & 0.26\end{array}$ \begin{tabular}{lllllllllllllllllllllllllllllll}
15 & 12 & $<5$ & $<5$ & 25 & 56 & 140 & 79 & 552 & 18 & 7.88 & 5.27 & 2.47 & 0.71 & 92.25 & 2.92 & 15.82 & 30.26 & 56.14 & 5.70 & 19.03 & 3.33 & 0.70 & 2.71 & 0.39 & 2.17 & 0.45 & 1.33 & 0.21 & 1.48 & 0.21 \\
\hline
\end{tabular} 
for $\mathrm{Fe}, 20 \%$ for the lower abundance elements $(\mathrm{Mg}$, $\mathrm{Ti}$ and $\mathrm{Cl}$ ) and $\sim 50 \%$ for $\mathrm{Mn}$ and $\mathrm{P}$ which are just above detection limit. Due to variable secondary hydration, all the glass analyses presented were normalized to $100 \%$ for comparative purposes.

\subsection{Dating}

Organic material in soils and sediment above and below the tephra layers helps to constrain ages of the explosive events. Samples were carefully obtained in the field, avoiding contamination such as modern roots mainly through clearing and digging back exposures, and then packaged in aluminum foil and dried at low temperature. Accelerator Mass Spectrometry (AMS) analyses were done and most samples were calibrated using the OxCal4.1 software (Bronk Ramsey, 2009) and the Southern Hemisphere calibration curve SHCal04 (McCormac et al., 2004), and were corrected for fractionation (Table 3). Ages are given as calibrated ranges before present (BP, where present is 1950) at the $95.4 \%$ confidence level.

\subsection{Sieving and grain-size}

Bulk pyroclastic samples were collected in most places, with reworked deposits avoided. All samples were dried in a box oven at no more than $50^{\circ} \mathrm{C}$ for less than 48 hours. Granulometric analyses of the coarse fraction were done on samples sieved at one-phi $(\phi)$ intervals from $-4 \phi(16 \mathrm{~mm})$ to $+4 \phi(1 / 16 \mathrm{~mm})$. Each fraction was then weighed to $0.01 \mathrm{~g}$ on a balance, and weight percentages calculated. Once raw grain size data were collected, size statistics such as median diameter $\left(\mathrm{Md}_{\phi}\right)$, sorting $\left(\sigma_{\phi}\right)$ and skewness $\left(\alpha_{\phi}\right)$ were computed (Table 4$)$. Sorting values $\left(\sigma_{\phi}\right)$ range from $0.8-1.93$, corresponding to moderately to poorly sorted deposits. Componentry analysis was also performed on selected samples in order to investigate the variety of particle compositions.

Grain-size distributions of the fine fraction of samples $(<4 \phi)$ were quantified using laser diffraction spectrometry (LDS), employing a Malvern Mastersizer Hydro 2000G at the Department of Geology of the University of Chile. The refractive indices for size-distribution calculation were 1.48 and 1.50; based on the high $\mathrm{SiO}_{2}$ content of the ash, the absorption index was set to 0.10 , as discussed by Horwell (2007).

\subsection{Volume estimates}

Volume estimates of tephra deposits were computed using a new empirical method proposed by Bonadonna and Costa (2012), based on the integration of the Weibull function. This method combines the advantages of exponential and power-law fits of the thickness-versus-distance data. The Weibull function is less sensitive than other functions to missing data, because it does not rely on the selection of segments needed for the application of other functions (for a review see Bonadonna and Costa, 2012). This insensitivity to missing data is relevant for deposits identified in this study where only a few isopach contours are available. Despite the exposure and distribution dependence of volume estimations, we expect uncertainties much less than an order of magnitude. Dense rock equivalent (DRE) volumes are not presented here, because systematic distributions of both pyroclasts and deposit density are not available.

\section{Results}

Major explosive eruptions have been reported for both Michinmahuida and Chaitén Volcanoes in previous studies. A thick andesitic scoria fall layer has been recognized several kilometers east of the volcanoes and is associated with Michinmahuida Volcano. This deposit is called Micl and dated at $7.3 \mathrm{ka}$ BP (Naranjo and Stern, 2004). Naranjo and Stern (2004) also identified a rhyolitic pumice fall, called Chal, and associated it with an eruption of Chaitén Volcano. Watt et al. (2011a) recognized the same deposit $160 \mathrm{~km}$ north in the Hualaihué region. They estimated its bulk tephra volume at $3.5 \mathrm{~km}^{3}$, and dated it at $9.75 \mathrm{ka} \mathrm{BP}$. Naranjo and Stern (2004) also identified a second rhyolitic pumice layer, the Mic2 unit, east of the volcanoes. Although it is rhyolite, it has a dispersal pattern similar to that of Micl, and they assigned it to an eruption of Michinmahuida. In contrast, Watt et al. (2009; 2013, this volume) correlated the unit to a proximal pyroclastic sequence north of Chaitén, and argued that it represents an eruption of Chaitén, not Michinmahuida. They named this event $\mathrm{Cha} 2$ and estimated its bulk tephra volume at $4.7 \mathrm{~km}^{3}$. That event has a radiocarbon date of about $4.95 \mathrm{ka}$ BP. Watt et al. (2013, this volume) also estimated a bulk tephra volume of $1.5 \mathrm{~km}^{3}$ for the Micl deposit. On 
TABLE 2. AVERAGE (AND STANDARD DEVIATION) GLASS MAJOR ELEMENT COMPOSITIONS AS DETERMINED BY ELECTRON MICROPROBE. NORMALISED TO 100\% ANHYDROUS BASE.

\begin{tabular}{|c|c|c|c|c|c|c|c|c|c|}
\hline Sample & $\mathrm{SiO}_{2}$ & $\mathrm{TiO}_{2}$ & $\mathrm{Al}_{2} \mathrm{O}_{3}$ & $\mathrm{FeO}$ & MnO & MgO & $\mathrm{CaO}$ & $\mathrm{Na}_{2} \mathrm{O}$ & $\mathbf{K}_{2} \mathbf{O}$ \\
\hline \multicolumn{10}{|l|}{ Chaitén Volcano } \\
\hline AA040311-1M $(n=25)$ & 76.74 & 0.09 & 13.47 & 1.18 & 0.06 & 0.18 & 1.03 & 3.81 & 3.28 \\
\hline $\begin{array}{l}\text { Rhyolite between Chal } \\
\text { and Cha2 (Mallines } \\
\text { section) }\end{array}$ & 0.36 & 0.03 & 0.23 & 0.06 & 0.04 & 0.02 & 0.04 & 0.47 & 0.07 \\
\hline AA010810-1B $(n=27)$ & 75.51 & 0.14 & 13.96 & 1.31 & 0.07 & 0.25 & 1.38 & 4.12 & 3.11 \\
\hline $\begin{array}{l}\text { pre-2008 lahar, Chaitén } \\
\text { River valley }\end{array}$ & 0.25 & 0.02 & 0.24 & 0.09 & 0.03 & 0.02 & 0.05 & 0.21 & 0.06 \\
\hline AA040311-1P $(\mathrm{n}=33)$ & 75.83 & 0.09 & 14.07 & 1.27 & 0.08 & 0.21 & 1.25 & 3.98 & 3.06 \\
\hline Chal (Mallines section) & 0.26 & 0.04 & 0.13 & 0.07 & 0.03 & 0.02 & 0.05 & 0.31 & 0.08 \\
\hline AA060311-3 $(\mathrm{n}=31)$ & 76.04 & 0.12 & 13.95 & 1.21 & 0.06 & 0.21 & 1.26 & 3.90 & 3.11 \\
\hline $\begin{array}{l}\text { Pumice flow, Chaitén } \\
\text { River valley }\end{array}$ & 0.31 & 0.03 & 0.12 & 0.06 & 0.03 & 0.02 & 0.03 & 0.32 & 0.07 \\
\hline AA040311-1G $(n=31)$ & 76.05 & 0.12 & 14.13 & 1.23 & 0.07 & 0.22 & 1.29 & 3.61 & 3.09 \\
\hline Cha2 (Mallines section) & 0.45 & 0.02 & 0.12 & 0.11 & 0.03 & 0.02 & 0.05 & 0.55 & 0.08 \\
\hline AA250110-1B $(n=32)$ & 75.60 & 0.13 & 13.80 & 1.35 & 0.07 & 0.26 & 1.40 & 4.15 & 3.07 \\
\hline $\begin{array}{l}\text { Few centuries old ash } \\
\text { (El Amarillo) }\end{array}$ & 0.28 & 0.03 & 0.15 & 0.09 & 0.04 & 0.02 & 0.05 & 0.19 & 0.08 \\
\hline \multicolumn{10}{|l|}{ Michinmahuida Volcano } \\
\hline LL230409-1 $(\mathrm{n}=4)$ & 62.12 & 1.22 & 15.36 & 7.18 & 0.18 & 1.63 & 4.41 & 4.50 & 2.77 \\
\hline $\begin{array}{l}\text { Amarillo ignimbrite (Tur- } \\
\text { bio Chico River valley) }\end{array}$ & 1.07 & 0.05 & 0.23 & 0.52 & 0.02 & 0.25 & 0.42 & 0.15 & 0.29 \\
\hline AA280110-3A $\quad(n=25)$ & 66.48 & 0.69 & 15.42 & 5.09 & 0.14 & 0.83 & 2.91 & 4.94 & 3.13 \\
\hline $\begin{array}{l}\text { Grey pumice (Turbio } \\
\text { Chico River valley) }\end{array}$ & 0.26 & 0.04 & 0.24 & 0.19 & 0.04 & 0.07 & 0.12 & 0.17 & 0.10 \\
\hline AA280110-3A $(n=13)$ & 67.49 & 0.66 & 15.32 & 4.67 & 0.12 & 0.65 & 2.59 & 4.79 & 3.34 \\
\hline $\begin{array}{l}\text { Glassy lithics in grey pu- } \\
\text { mice (Turbio Chico River } \\
\text { valley) }\end{array}$ & 1.33 & 0.08 & 0.44 & 0.64 & 0.06 & 0.24 & 0.35 & 0.14 & 0.33 \\
\hline \multicolumn{10}{|l|}{ ODP site 1233} \\
\hline \multirow[t]{2}{*}{ silicic clasts $(n=7)$} & 70.57 & 0.35 & 14.47 & 3.57 & 0.12 & 0.27 & 1.65 & 5.17 & 3.53 \\
\hline & 0.93 & 0.07 & 0.79 & 0.47 & 0.04 & 0.11 & 0.35 & 0.39 & 0.28 \\
\hline \multirow[t]{2}{*}{ mafic clasts $(n=3)$} & 56.24 & 1.72 & 15.65 & 9.67 & 0.19 & 3.33 & 6.74 & 4.15 & 1.63 \\
\hline & 0.55 & 0.03 & 0.12 & 0.26 & 0.03 & 0.12 & 0.18 & 0.20 & 0.01 \\
\hline
\end{tabular}




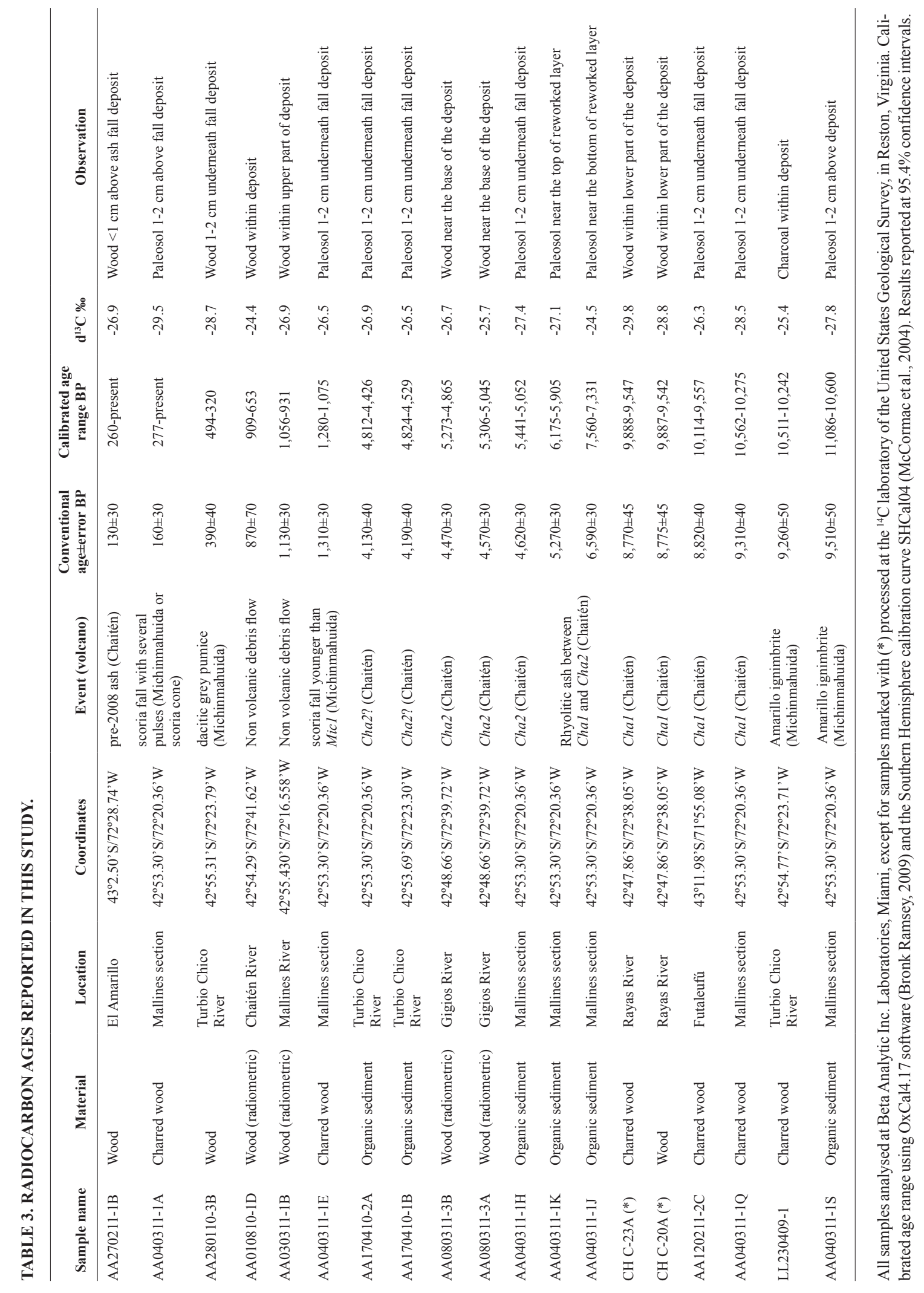


TABLE 4. GRANULOMETRIC PARAMETERS FOR SELECTED TEPHRA SECTIONS.

\begin{tabular}{|c|c|c|c|c|c|c|c|c|}
\hline Sample name & $\begin{array}{l}\text { Distance from the } \\
\text { volcano and direction }\end{array}$ & $\begin{array}{c}\text { Thickness } \\
\text { cm }\end{array}$ & $\mathbf{M d}_{\phi}$ & Md mm & $\sigma_{\phi}$ & $\alpha_{\phi}$ & MP/ML & Lithics \\
\hline \multicolumn{9}{|l|}{ Cha1 } \\
\hline AA040311-1P & $26 \mathrm{~km} / \mathrm{N} 103^{\circ} \mathrm{E}$ & 70 & -1.63 & 3.08 & 1.19 & -1.37 & $2.4 / 1.2$ & $\begin{array}{l}\text { andesitic lava }>\text { greenschists } \\
>>\text { obsidian/rhyolite }\end{array}$ \\
\hline AA140211-1 & $16 \mathrm{~km} / \mathrm{N} 23^{\circ} \mathrm{E}$ & 125 & -2.24 & 4.74 & 1.76 & -1.46 & $6.0 / 3.0$ & $\begin{array}{l}\text { granitoid } \sim \text { Andesitic lava } \\
>\text { greenschist }>\text { obsidian/ } \\
\text { rhyolite }\end{array}$ \\
\hline AA270710-1 & $24 \mathrm{~km} / \mathrm{N} 12^{\circ} \mathrm{E}$ & 30 & -1.53 & 2.88 & 1.32 & -1.09 & $3.8 / 0.5$ & $\begin{array}{l}\text { andesitic lava }>\text { greenschist } \\
\sim \text { granitoid }>\text { obsidian/ } \\
\text { rhyolite }\end{array}$ \\
\hline
\end{tabular}

\section{Cha2}

\begin{tabular}{|c|c|c|c|c|c|c|c|c|}
\hline AA260110-2 & $10 \mathrm{~km} / \mathrm{N} 94^{\circ} \mathrm{E}$ & $>100$ & -2.59 & 6.01 & 1.93 & -1.7 & $4.12 / 3.10$ & $\begin{array}{l}\text { granitoid }>\text { obsidian/rhyo- } \\
\text { lite }>\text { lava }\end{array}$ \\
\hline AA040311-1G & $26 \mathrm{~km} / \mathrm{N} 103^{\circ} \mathrm{E}$ & 95 & -2.61 & 6.09 & 1.49 & -1.66 & $4.05 / 1.95$ & $\begin{array}{l}\text { obsidian/rhyolite }>>\text { andes- } \\
\text { itic lava }\end{array}$ \\
\hline AA230409-1 & $22 \mathrm{~km} / \mathrm{N} 107^{\circ} \mathrm{E}$ & 60 & -1.7 & 3.24 & 0.91 & -2.04 & $3.18 / 0.75$ & $\begin{array}{l}\text { obsidian/rhyolite }>\text { andesitic } \\
\text { lava }>>\text { greenschits }\end{array}$ \\
\hline AA180410-1B & $25 \mathrm{~km} / \mathrm{N} 125^{\circ} \mathrm{E}$ & 20 & -0.42 & 1.34 & 1.23 & -0.08 & $0.45 / 0.15$ & $\begin{array}{l}\text { obsidian/rhyolite }>\text { andes- } \\
\text { itic lava }\end{array}$ \\
\hline AA130211-3D & $85 \mathrm{~km} / \mathrm{N} 88^{\circ} \mathrm{E}$ & 60 & -1.11 & 2.16 & 0.8 & -1.18 & $1.48 / 0.30$ & $\begin{array}{l}\text { obsidian/rhyolite }>\text { andes- } \\
\text { itic lava }\end{array}$ \\
\hline
\end{tabular}

\section{Mic1}

$\begin{array}{llrrrrrrl}\text { AA230409-2 } & 12 \mathrm{~km} / \mathrm{N} 156^{\circ} \mathrm{E} & 20 & -2.85 & 7.21 & 1.28 & -1.76 & 3.54 / \text { - } & \text { andesitic lava } \\ \text { AA040311-1I } & 13 \mathrm{~km} / \mathrm{N} 139^{\circ} \mathrm{E} & 15 & -1.36 & 2.57 & 1.46 & -0.74 & 2.23 /- & \text { andesitic lava } \\ \text { AA130211-3B } & 67 \mathrm{~km} / \mathrm{N} 91^{\circ} \mathrm{E} & <10 & -0.06 & 1.05 & 1.83 & 0.45 & 1.5 /- & \text { andesitic lava }\end{array}$

\section{Grey Pumice}

$\begin{array}{llrrrrrrr}\text { AA170410-1C } & 12 \mathrm{~km} / \mathrm{N} 156^{\circ} \mathrm{E} & 25 & -1.7 & 3.25 & 1.39 & -1.17 & 3.20 / 0.72 & \text { dacitic lava }>\text { andesitic lava } \\ \text { AA280110-3A } & 14 \mathrm{~km} / \mathrm{N} 164^{\circ} \mathrm{E} & 17 & -0.92 & 1.89 & 1.68 & -0.44 & 2.46 / 0.40 & \text { dacitic lava }>\text { andesitic lava } \\ \text { AA280710-1A } & 16 \mathrm{~km} / \mathrm{N} 163^{\circ} \mathrm{E} & 6 & -0.65 & 1.57 & 1.4 & -0.45 & 2.20 /- & \text { dacitic lava }>\text { andesitic lava }\end{array}$

'MP'= Average of maximun axis of five largest pumice clasts; 'ML'= Average of maximun axis of five largest lithic clasts.

the basis of field sampling and results from several analytical techniques, we present evidence confirming the revised correlations of these events, but we also present evidence of previously unreported events. The chronological framework presented here matches relatively well with previously reported data. By combining all available observations, we update volume estimates of eruptive deposits and improve the record of explosive activity for these two volcanoes.

Tens of pyroclastic sections were sampled around both volcanoes, in particular along the Chaitén, Amarillo, Michinmahuida, Turbio Chico and Mallines river valleys (Fig. 1). Also distal sections were examined along the Espolón and Futaleufú valleys and the northern shore of Futalaufquén Lake, Argentina, about $25 \mathrm{~km}$ east of Esquel (Fig. 1). The most complete pyroclastic sequence reported in this study is a $>20$-m-thick section located along the Mallines River $\left(42.887^{\circ} \mathrm{S}, 72.338^{\circ} \mathrm{W}\right)$, near the confluence with the Michinmahuida River, and $13 \mathrm{~km}$ southeast of Michinmahuida Volcano (Fig. 2). This site provides a favorable position that recorded explosive activity from both volcanoes. In this section, six scoria fall and three pumice-and-ash fall deposits were identified including the Micl, Chal and Cha2 deposits. An additional silicic ash layer younger than Chal but older than Cha2 was recognized. The lower half of the section is composed of an ignimbrite deposit, which has not been described previously. 


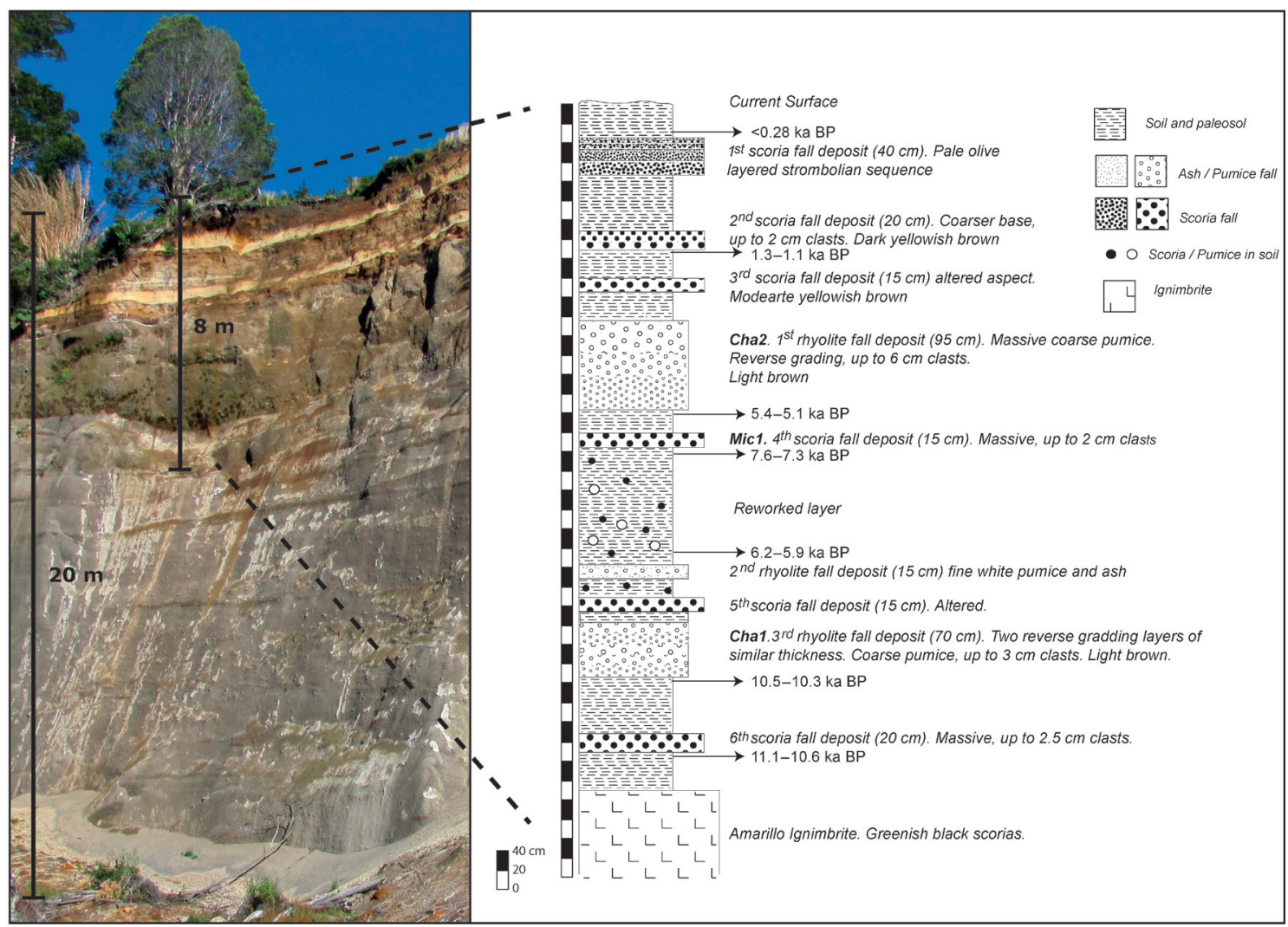

FIG. 2. Stratigraphy at the Mallines section. Ages are given as calibrated ranges in thousand years (ka) before present (BP), where present is 1950 .

The base of the deposit is not exposed. A section on the upper southern flank of Michinmahuida Volcano $\left(42.863^{\circ} \mathrm{S}, 72.435^{\circ} \mathrm{W}\right)$ complements the events recorded at the Mallines section, including four deposits that may be derived from local pyroclastic cones.

Major and trace elements in samples collected along the Mallines River valley section and at a few other locations show a wide range of compositions (Table 1). Silica contents for some scoria samples seem anomalously low for products from Michinmahuida Volcano, and those same samples show very high loss on ignition (LOI) contents up to $13 \%$, which is likely related to weathering processes (see discussion below). On the basis of immobile trace elements contents such as Co and Th (Hastie et al., 2007) they likely represent basaltic-andesite and basaltic compositions. Samples analyzed from the 'rhyolite fall desposits' (Fig. 2) lie on the boundary between dacite and rhyolite fields (Fig. 3a), although they are likely to be Chaitén rhyolites. For this reason, high-silica samples are further addressed using glass chemistry instead of whole-rock analyses. Accordingly, trace-element ratios provide signatures that help identify volcanic sources, even for weathered samples. Relationships between ratios of the rareearth elements $\mathrm{La}$ and $\mathrm{Yb}$, and elements of similar fluid mobility, $\mathrm{Zr}$ and $\mathrm{Nb}$ (Fig. 3b), suggest that the scoria and pumice samples are derived from at least two different sources: one source representing highly fractionated rare-earth elements and low $\mathrm{Zr} / \mathrm{Nb}$ ratios, similar to products associated with Chaitén Volcano; and a second source that shows an opposite relationship, common for other volcanoes in the southernmost SVZ.

As indicated above, a remarkable feature of several samples is the high LOI value (Table 1). After re-calculating the original compositions on a $100 \%$ anhydrous basis, some samples show compositions not considered as magmatic (Fig. 3a). The anomalously low silica contents are likely related 

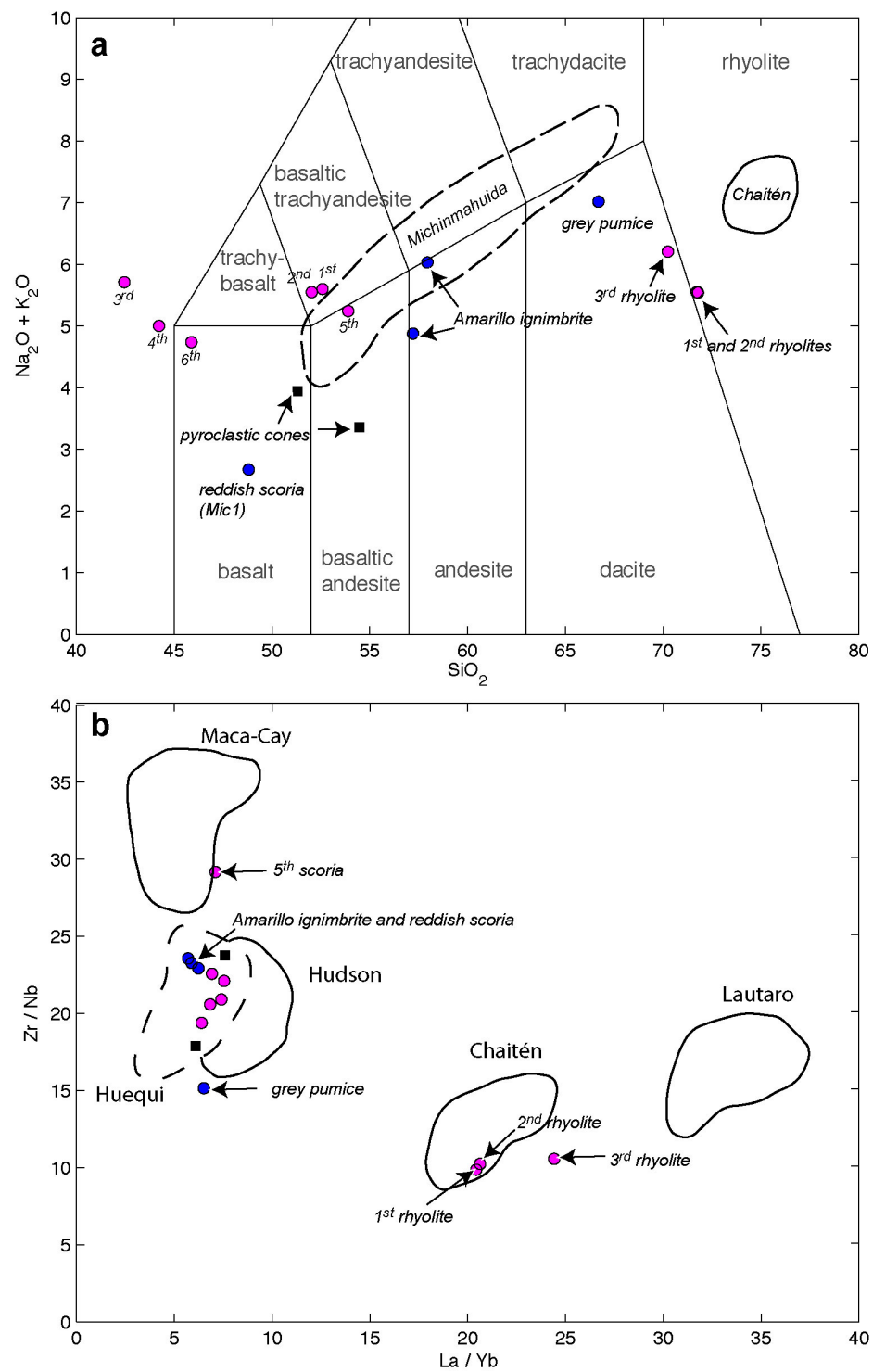

FIG. 3. Whole-rock compositions (single analyses) of pumice and scoria from Chaitén and Michinmahuida volcanoes. a. Total alkalis versus silica diagram (TAS) normalized anhydrous compositions; b. Trace element compositions. Solid magenta circles represent pyroclasts from the Mallines section (cf. Fig. 2) which are labeled as $1^{\text {st }}$ to $6^{\text {th }}$ scoria and $1^{\text {st }}$ to $3^{\text {rd }}$ rhyolitic pumices. Solid blue circles represent samples thought to be derived from Michinmahuida Volcano. Fields of other Chaitén and Michinmahuida data and other volcanoes from López-Escobar et al. (1993), Stern and Kilian (1996), D’Orazio et al. (2003), Stern (2008) and Watt et al. (2011b) are shown.

to weathering and alteration to clay minerals, owing to regional annual rainfall totals up to $4,000 \mathrm{~mm} / \mathrm{yr}$ (Garreaud, 2009). High water-to-rock ratios have direct effects on element mobility. XRD analyses conducted on pumices and scorias indicate the presence of secondary minerals derived from weathering of alumino-silicate minerals (e.g., kaolinite and gibbsite) or formed by weathering of iron- and magnesiumbearing minerals (e.g., vermiculite and chrysotile).

Naranjo and Stern (2004) reported several pyroclastic fall deposits located downwind of Chaitén and Michinmahuida Volcanoes, and they suggested other volcanoes as possible sources. At several sites located around Esquel and Futalaufquén, Argentina, they suggested that pumice-and-ash fall deposits were derived from Michinmahuida (90 km to the west), Corcovado (125 km to the southwest) and Yanteles (140 km to the southwest) volcanoes, and they named the tephra layers as Mic1, Mic2, Cor2, Cor3 and Yan1. However, that study is based on limited field sampling (lacking proximal sites). Furthermore, chemical fingerprints of the deposits are poorly constrained. Hence, their assignment of the deposits to specific volcanoes might not be correct. In addition, 
Naranjo and Stern (2004) did not recognize Chaitén as one of the potential sources for those deposits, despite the rhyolitic composition obtained for the Mic2 deposit. Using $\mathrm{Zr} / \mathrm{TiO}_{2}$ ratios, we can show that the Mic2, Cor 2 and Yan 1 samples from Naranjo and Stern (2004) collected in Esquel, Argentina, fall within the evolved $(>0.030)$ composition range of Pearce (1996), whereas the Micl and Cor3 samples have intermediate $(<0.030)$ compositions. The Chal deposit of Naranjo and Stern (2004) and the products derived from the 2008 eruption of Chaitén also fall within the evolved composition range. Another source of evolved Holocene products is Huequi Volcano $\left(42.23^{\circ} \mathrm{S}, 72.35^{\circ} \mathrm{W}, 1,320 \mathrm{~m}\right.$ a.s.1.), located $50 \mathrm{~km}$ north of Chaitén Volcano (e.g. López-Escobar et al., 1993). However, though explosive activity has been recognized in proximal outcrops near this volcano, no widespread tephra deposits have yet been linked to Huequi (Watt et al., 2011b).

\section{Volcanic events}

Here, we present detailed descriptions for the main units we have identified. We discuss regional distributions, macroscopic aspects, chemistry, volume estimates and age constraints of the deposits. A summary of all events identified in this study and their potential correlations with previously reported events is shown in the Table 5.

\subsection{Major events}

\subsubsection{Amarillo ignimbrite.}

The Amarillo ignimbrite is a dark, nonwelded diamict that crops out around Michinmahuida Volcano (Lara et al., 2009). Owing to dense vegetation and poor accessibility, this unit was first identified through aerial photographs. Visits to several field sites confirmed its pyroclastic nature. Based on the spatial distribution of the deposit and its chemical signature (Fig. 3a, b), we attribute this event to a large ignimbrite-forming eruption from Michinmahuida Volcano. That eruption may have created the now ice-filled caldera present on the upper part of the volcano.

The partially incised ignimbrite deposit is confined to the main valleys surrounding Michinmahuida, including the Amarillo, Michinmahuida, Mallines and Rayas River valleys (Fig 4a). It has a characteristically flat top which in some places is covered by younger lava flows from local pyroclastic cones, in particular near the Rayas, Amarillo and Michinmahuida Rivers. The deposit is up to $80 \mathrm{~m}$ thick and is preserved up to $20 \mathrm{~km}$ from the present-day summit of Michinmahuida. Most of the observed deposit is composed of massive pyroclastic flow units having ill-defined upper and lower boundaries. Most accidental clasts are of volcanic origin, including rhyolitic pumices, dense lithics, but also minor granitoid clasts. The most prominent juvenile products of this ignimbrite are coarse andesitic bread-crusted bombs having fresh appearance. A thin section from one bomb sample contains $c a$. 15 vol.\% vesicles, and the main phenocrysts are composed of plagioclase and clinopyroxene (augite). Minor Fe-Ti oxides (magnetic minerals of moderate strength) also have been identified using a hand magnet. Whole-rock compositions for two samples (Table 1) have andesitc composition. The matrix of the ignimbrite is composed of poorly sorted, scoriaceous, dark ash and lapilli.

A sample of charcoal collected within the deposit along the Michinmahuida River, $13 \mathrm{~km}$ SE from the volcano, yields an age about 10.5-10.2 ka BP. Organic-rich sediment immediately above the ignimbrite at the Mallines section yields an age of about 11.1-10.6 ka BP (Table 3). These calibrated ages bracket the calibrated 10.7-10.3 ka BP reported by Naranjo and Stern (2004) for a mafic pyroclastic surge deposit that underlies a rhyolitic pumice fall deposit north of Chaitén Volcano along the road between Santa Bárbara and Caleta Gonzalo (Fig 1). Chemical analyses are not available for the juvenile material in that surge deposit, but the similarities of age and the composition inferred from the macroscopic description suggest that the deposits could be related to a single large event from Michinmahuida.

Using an SRTM digital elevation model (Farr et al., 2007), we estimate a pre-erosion noncompacted volume of $c a .10 \mathrm{~km}^{3}$ for the ignimbrite. However, because the base of the deposit has not been observed, this is a minimum volume estimate. The eruption that produced this ignimbrite deposit is likely one of the largest eruptive events in the SVZ during the Holocene. Such activity constitutes an important potential hazard derived from this volcano.

Tephra fall deposits definitively related to this eruptive event have not been found thus far; however, there is evidence indicating extensive tephra fall in the region at the time proposed for 
TABLE 5. SUMMARY OF VOLCANIC EVENTS IDENTIFIED IN THIS STUDY.

\begin{tabular}{|c|c|c|c|c|c|}
\hline Event & Source & Composition & Age & Outcrops & Potential Correlation \\
\hline 1 & Scoria cone? & Basaltic-andesite? & n.a. & $\begin{array}{l}\text { Upper southern flank of } \\
\text { Michinmahuida Volcano }(3-4 \mathrm{~cm})\end{array}$ & 1835 AD? (Darwin, 1840) \\
\hline \multirow[t]{2}{*}{2} & Chaitén & Rhyolite & $<0.3 \mathrm{ka} \mathrm{BP}$ & $\begin{array}{l}\text { Upper southern flank of } \\
\text { Michinmahuida Volcano }(6-7 \mathrm{~cm})\end{array}$ & $\begin{array}{l}17^{\text {th }} \text { century eruption, } 1625- \\
1658 \mathrm{AD} \text { (Lara et al., } 2013 \text {, } \\
\text { this volume) }\end{array}$ \\
\hline & & & paleosol underneath (Amarillo) & $\begin{array}{l}\text { Turbio Chico River valley }(10 \text { to } 30 \mathrm{~cm}) \\
\text { El Amarillo }(5 \mathrm{~cm})\end{array}$ & $\begin{array}{l}\text { Cha4 or Cha3? (Watt et al., } \\
2013 \text {, this volume) }\end{array}$ \\
\hline 3 & Scoria cone? & Basaltic-andesite & $\begin{array}{l}<0.3 \mathrm{ka} \mathrm{BP} \\
\text { paleosol above (Mallines) }\end{array}$ & $\begin{array}{l}\text { Upper southern flank of } \\
\text { Michinmahuida Volcano }(6-7 \mathrm{~cm}) \\
\text { Turbio Chico River valley }(10 \text { to } 30 \mathrm{~cm}) \\
\text { Mallines section }(40 \mathrm{~cm})\end{array}$ & not known \\
\hline \multirow[t]{2}{*}{4} & Michinmahuida & Dacite & $0.5-0.3 \mathrm{ka} \mathrm{BP}$ & $\begin{array}{l}\text { Upper southern flank of Michinmahuida } \\
\text { Volcano }(30 \mathrm{~cm})\end{array}$ & not known \\
\hline & & & paleosol underneath (Mallines) & Turbio Chico River valley (10 to $25 \mathrm{~cm}$ ) & \\
\hline 5 & Michinmahuida & Andesite & $\begin{array}{l}1.3-1.1 \mathrm{ka} \text { BP } \\
\text { paleosol underneath (Mallines) }\end{array}$ & Mallines section $(20 \mathrm{~cm})$ & not known \\
\hline 6 & Michinmahuida & Andesite & n.a. & Mallines section $(15 \mathrm{~cm})$ & not known \\
\hline \multirow[t]{2}{*}{7} & Chaitén & Rhyolite & 5.3-4.9 ka BP & Mallines section $(95 \mathrm{~cm})$ & $\begin{array}{l}\text { Cha2 (Watt et al., 2011a; 2013, } \\
\text { this volume) }\end{array}$ \\
\hline & & & $\begin{array}{l}\text { charcoal within PDC deposit } \\
\text { (Gigios) }\end{array}$ & $\begin{array}{l}\text { Turbio Chico River valley }(10 \text { to } 60 \mathrm{~cm}) \\
\text { Upper southern flank of Michinmahuida } \\
\text { Volcano }(20 \mathrm{~cm}) \\
\text { West of Michinmahuida Volcano }(>100 \mathrm{~cm}) \\
\text { Futalaufquén Lake, northern shore }(60-65 \mathrm{~cm}) \\
\text { Gigios River, pdc }(>10 \mathrm{~m})\end{array}$ & Mic2 (Naranjo and Stern, 2004) \\
\hline 8 & Michinmahuida & Andesite & $\begin{array}{l}\text { 7.6-7.3 ka BP } \\
\text { paleosol underneath (Mallines) }\end{array}$ & $\begin{array}{l}\text { Mallines section }(15 \mathrm{~cm}) \\
\text { Turbio Chico River valley }(10 \text { to } 20 \mathrm{~cm}) \\
\text { Futalaufquén Lake, northern shore }(7-8 \mathrm{~cm}) \\
\text { Upper southern flank of Michinmahuida } \\
\text { Volcano }(30 \mathrm{~cm})\end{array}$ & Micl (Naranjo and Stern, 2004) \\
\hline 9 & Scoria cone? & Basaltic-andesite? & n.a. & $\begin{array}{l}\text { Upper sourthern flank of Michinmahuida } \\
\text { Volcano }(8 \mathrm{~cm})\end{array}$ & not known \\
\hline 10 & Scoria cone? & Basaltic-andesite? & n.a. & $\begin{array}{l}\text { Upper southern flank of Michinmahuida } \\
\text { Volcano }(5 \mathrm{~cm})\end{array}$ & not known \\
\hline 11 & Chaitén & Rhyolite & $\begin{array}{l}>7.6-7.3 \mathrm{ka} \mathrm{BP} ? \\
\text { paleosol above (Mallines) }\end{array}$ & $\begin{array}{l}\text { Mallines section }(15 \mathrm{~cm}) \\
\text { Upper southern flank of Michinmahuida } \\
\text { Volcano }(15 \mathrm{~cm})\end{array}$ & not known \\
\hline 12 & Michinmahuida & Andesite? & n.a. & $\begin{array}{l}\text { Mallines section }(15 \mathrm{~cm}) \\
\text { Upper southern flank of Michinmahuida } \\
\text { Volcano }(5 \mathrm{~cm})\end{array}$ & not known \\
\hline 13 & Chaitén & Rhyolite & $\begin{array}{l}\text { 9.9-9.6 ka BP } \\
\text { wood within fall deposit } \\
\text { (Rayas) }\end{array}$ & $\begin{array}{l}\text { Sta. Bárbara - Caleta Gonzalo }(20-120 \mathrm{~cm}) \\
\text { Mallines section }(70 \mathrm{~cm}) \\
\text { Upper southern flank of Michinmahuida } \\
\text { Volcano }(140 \mathrm{~cm})\end{array}$ & $\begin{array}{l}\text { Chal (Naranjo and Stern, } \\
\text { 2004) }\end{array}$ \\
\hline 14 & Michinmahuida & Andesite? & $11.1-10.6 \mathrm{ka} \mathrm{BP}$ & Mallines section $(20 \mathrm{~cm})$ & $\begin{array}{l}\text { Tephra on Chiloé Island? } \\
\text { (Heusser et al., 1995) }\end{array}$ \\
\hline & & & paleosol underneath (Mallines) & & \\
\hline 15 & $\begin{array}{l}\text { Michinmahuida } \\
\text { (Amarillo } \\
\text { ignimbrite) }\end{array}$ & Andesite? & $\begin{array}{l}\text { 10.5-10.2 ka BP } \\
\text { charcoal within deposit (Turbio } \\
\text { Chico) }\end{array}$ & $\begin{array}{l}\text { Turbio Chico River valley, pdc }(>60 \mathrm{~m}) \\
\text { Mallines section, pdc }(>15 \mathrm{~m})\end{array}$ & not known \\
\hline
\end{tabular}

'pdc'= pyroclastic density current; ' $\mathbf{n} . \mathbf{a}$ '= not available. 

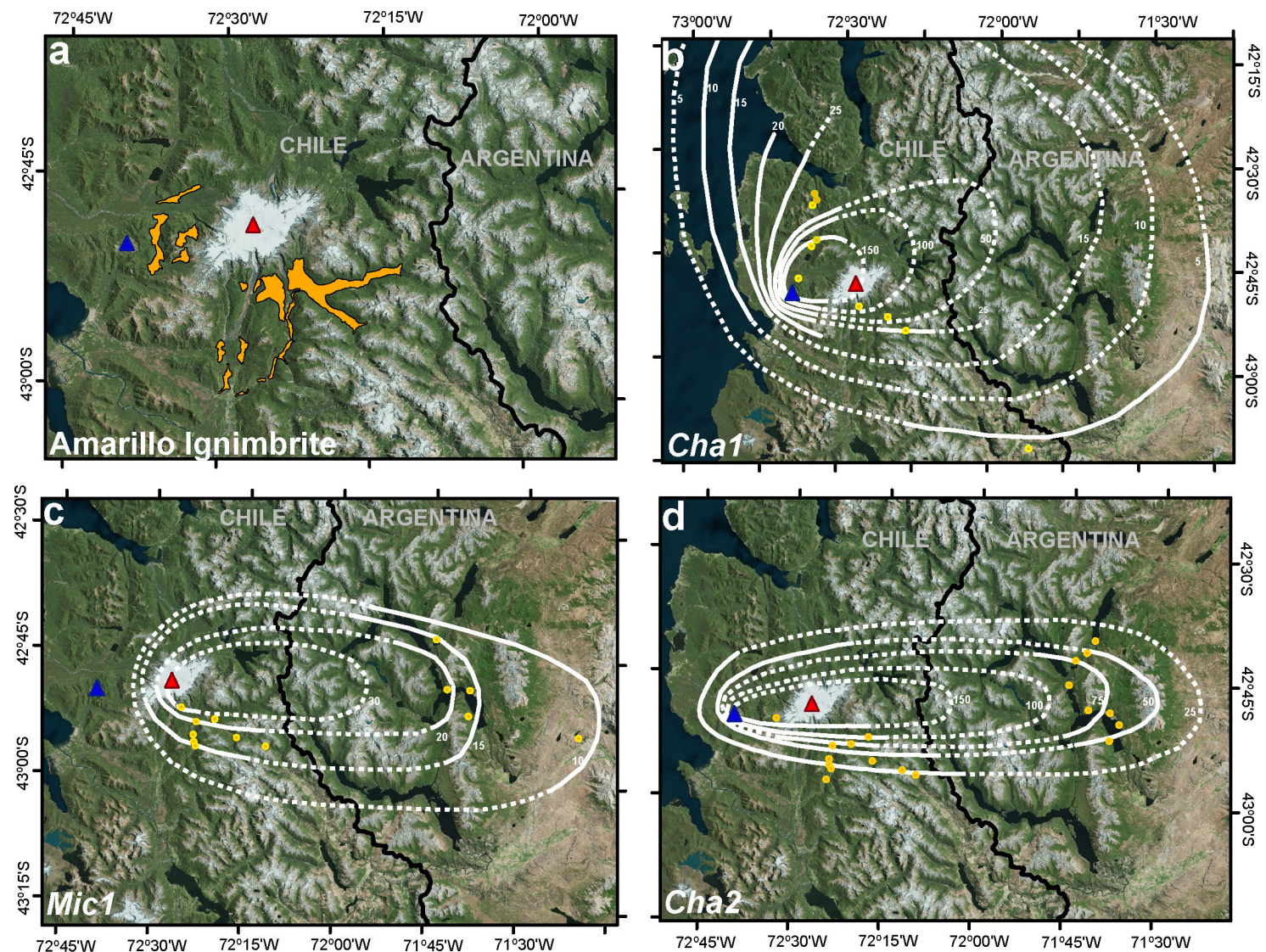

FIG. 4. a. Extent of deposits that have been correlated to the Amarillo ignimbrite. Isopach maps (in $\mathrm{cm}$ ) estimated for the b. Chal eruption; c. Micl event; and d. Cha2 eruption. Solid (dash) lines represent well (ill) constrained isopachs. Yellow dots indicate sites where thickness measurements were done. Chaitén and Michinmahuida volcanoes are indicated as blue and red triangle respectively.

ignimbrite emplacement. For example, Heusser et al. (1995) reported that Holocene sedimentary sequences on Chiloé Island consistently contain a tephra layer dated about 10.8-10.6 ka BP. In addition, a prominent tephra layer dated $c a .11 \mathrm{ka} \mathrm{BP}$ has been reported in paleo-climate studies in the region (Heusser et al., 1992; Moreno et al., 1999; Moreno, 2004; Abarzúa et al., 2005). Unfortunately, compositions for those deposits are unknown. Mix et al. (2003) reported an 8-cm-thick dark ash layer of intermediate composition in the Ocean Drilling Program (ODP) site 1233, located $38 \mathrm{~km}$ offshore in more than $800 \mathrm{~m}$ water depth $260 \mathrm{~km}$ northwest from Michinmahuida Volcano. This layer has been dated between 10.5 and 11.0 ka BP (Lamy and Kaiser, 2009) and it has the highest magnetic susceptibility of the entire core at site 1233 . However, glass chemistry for this tephra does not fit with Michinmahuida compositions (Table 2). A few studies describe tephra layers on the eastern side of the Andes having ages of $c a .11 \mathrm{ka} \mathrm{BP}$, in particular at Lake Mascardi (Hajdas et al., 2003). A large event is reported in northern Patagonia (Villarrosa et al., 2006), which was large enough to have triggered roof collapses in at least a couple of archeological sites and forced abandonment of the sites. Nevertheless, further studies are necessary in order to establish a positive correlation of these tephra layers to explosive activity at Michinmahuida Volcano.

Mix, A.C.; Tiedemann, R.; Blum, P.; Abrantes, F.F.; Benway, H.; Cacho-Lascorz, I.; Chen, M.T.; Delaney, M.; Flores, J.A.; Giosan, L.; Holbourn, A.E.; Irino, T.; Iwai, M.; Joseph, L.H.; Kleiven, H.F.; Lamy, F.; Lund, S.P.; Martínez, P.; McManus, J.F.; Ninnemann, U.S.; Pisias, N.G.; Robinson, R.S.; Stoner, J.S.; Sturm, A.; Wara, M.W.; Wei, W. 2003. Proceedings of the Ocean Drilling Program. Initial Reports Volume 202. doi: 10.2973/odp.proc.ir.202.2003. 


\subsubsection{Cha1}

The Chal fall deposit was thought to have originated from the only Holocene eruption of Chaiten Volcano prior to 2008. Chal was first described in a proximal setting as a white to yellow coarse pumice layer by Naranjo and Stern (2004), and as a pink-white coarse ash at distal sites ( $>100 \mathrm{~km}$ from the volcano) by Watt et al. (2011a). In both studies, a northward directed dispersal was inferred based on the spatial distribution of outcrops. However, in this study we have correlated this event to coarse pumice fall deposits located tens of $\mathrm{km}$ east of the volcano, suggesting a complex dispersal pattern. This revised dispersal pattern also increases the estimated volume of the deposit.

At similar distances from the volcano $(\sim 25 \mathrm{~km})$, but along different dispersal directions (NNE and $\mathrm{E})$, the granulometric median grain size of the Chal deposit is roughly $3 \mathrm{~mm}$ (Table 4 ), which indicates that eastward dispersion may have been as important as northward dispersion during the eruption. Variations in tephra dispersal patterns during single volcanic eruptions are not rare in the southern Andes (e.g., Scasso et al., 1994; Watt et al., 2009, Osores et al., 2013, this volume) and they can add complexities to the understanding of grain-size distributions of deposits. Therefore, sampling of many fall sections is necessary to determine the evolution of the Chal eruption. As a recent example, during the 1980 Mount St. Helens eruption, changes from ash to pumice lapilli fallout at the same site were reported as a result of differential transport of tephra at different altitudes (e.g., Sarna-Wojcicki et al., 1981).

The Chal deposits crop out mostly north of Chaitén Volcano, along the road between the Rayas River and Caleta Gonzalo. There, the deposit consists mainly of a thick and coarse pumice layer. We have identified a similar deposit east of the volcano, in particular in the Mallines section as a $70-\mathrm{cm}$-thick pumice layer composed of two reversely graded units of similar thickness separated by a sharp contact. The lower unit is slightly finer grained, which may support the idea of a complex dispersal pattern. However, this is the only site where we have observed such texture.

Based on the age and macroscopic appearance of the pumice grains, we also correlate Chal to a 5-cm-thick, yellow, fine lapilli fall deposit south of Futaleufú town, more than $70 \mathrm{~km}$ southeast of Chaitén Volcano (Fig. 1). Interestingly, Chal-related deposits usually contain less rhyolitic lithics and obsidian compared to other volcanic (such as andesitic) and non-volcanic lithics such as greenschists and granitoids. Metamorphic rocks and granitoids make up most of the basement at Chaitén Volcano (Piña-Gauthier et al., 2013, this volume). The low proportion of rhyolitic clasts may indicate that a small-volume dome complex was built at Chaitén Volcano prior to this early Holocene eruption but after the retreat of full glacial ice-sheets, which began in the region around $17 \mathrm{ka} \mathrm{BP}$ (Denton et al., 1999). We have not found deposits derived from explosive events older than this eruption, but the ubiquitous presence of rhyolitic pumices as accidental clasts within the Amarillo ignimbrite suggests there may have been earlier eruptions.

We have not observed deposits related to Chal eruption at elevations higher than $1 \mathrm{~km}$ asl, although younger deposits are present. One interpretation is that unconsolidated fall deposits would have been removed as a consequence of high erosion rates related to millennial-scale climate variability during the Holocene (Porter, 2000). High erosion rates in the early-to-mid Holocene are supported by the study of Douglass et al. (2005), who demonstrated glacial advance and increase in precipitation in northern Patagonia at 8.5 and $6.2 \mathrm{ka} \mathrm{BP}$, in connection with westerly winds shifting. Also, evidence of a wet phase in the mid-Holocene, in particular between 7.6 and $4.1 \mathrm{ka} \mathrm{BP}$, is derived from pollen records at $c a .42^{\circ} \mathrm{S}$ (Moreno, 2004). Another possibility is that fall deposits were deposited directly on ice and therefore not preserved.

The best age control for the Chal deposit comes from two charcoal samples from a thick pumiceblock-bearing deposit identified near the bridge over the Rayas River (Table 3 ) and dated about 9.9-9.5 ka BP (written communication, J. Pallister, 2011). The age of this proximal deposit correlates well with the age reported by Watt et al. (2011a) for Chal in the Hualaihué region ( $c a .9 .75 \mathrm{ka} \mathrm{BP}$ ), but is slightly younger than the (calibrated) age 10.7-10.3 ka BP proposed by Naranjo and Stern (2004). We suggest that their age for Chal could be representative of the Amarillo ignimbrite, because these authors dated a dark-grey surge deposit beneath the Chal fallout deposit and they did not present chemistry for the surge that indicated a correlation between both deposits. The lack of soil development between deposits is the only evidence that they presented to 
justify that the surge and Chal deposits are derived from the same eruption.

We have estimated the Chal tephra fall as having a bulk volume of $c a .5 .5 \mathrm{~km}^{3}$, based on isopachs (Fig. 4b) we have modified from Watt et al. (2011a). Our updated volume estimate implies that Chal is the largest known eruption of Chaitén Volcano during the Holocene. This result is in contrast to Watt et al. (2013, this volume), because they did not recognize outcrops of this event to the east of the volcano.

\subsubsection{Mic1}

The Micl deposit was identified by Naranjo and Stern (2004), as being from the older of two explosive events occurring at Michinmahuida Volcano in the mid- to late-Holocene. These authors based their interpretation upon fall deposits found in Argentina, mostly around Futalaufquén Lake and near Esquel. They inferred that the Micl deposit resulted from a medium size explosive eruption (VEI >3) about 7.4-7.0 ka BP. We have found correlative deposits east and southeast of Michinmahuida Volcano. Those deposits consist of a coarse reddish scoria fall of andesitic composition. The deposits have an incipient normal grading and contain a small proportion of dense lithic clasts, consisting of lava fragments of inferred intermediate compositions. The deposits fall along a marked E-SE dispersion axis. Approximately $10 \mathrm{~km}$ southeast of the volcano, the $\mathrm{Micl}$ deposit is about $20 \mathrm{~cm}$ thick and has a median grain diameter of more than $7 \mathrm{~mm}$. It is one of the coarsest-grained fall deposits observed at this distance. Both thickness and grain size decrease rapidly north and south of this dispersal axis. We have identified this deposit as far as $70 \mathrm{~km}$ east of Michinmahuida Volcano, where it is less than $10 \mathrm{~cm}$ thick, but has a median grain diameter of $1 \mathrm{~mm}$ (Table 4). At the Mallines section (Fig. 2), we dated a paleosol directly beneath the Micl deposit at 7.6-7.3 $\mathrm{ka} \mathrm{BP}$. That date is in agreement with the inferred age for this deposit reported by Naranjo and Stern (2004). On the basis of deposit thicknesses reported by Naranjo and Stern (2004) and our additional observations, we delineated a generalized isopach map (Fig. 4c) and estimated the volume of this deposit at $2 \mathrm{~km}^{3}$, within the order of magnitude of the estimated volume reported by Watt et al. (2013, this volume).

\subsubsection{Cha2}

The Cha2 deposit was first identified and called the Mic2 deposit by Naranjo and Stern (2004). They inferred that it was from a mid- to late-Holocene (ca. $5.0 \mathrm{ka} \mathrm{BP}$ ) eruption of Michinmahuida Volcano. Watt et al. (2009), however, concluded that it is from an eruption of Chaitén Volcano on the basis of whole-rock chemistry. The fall deposit associated with the Cha2 eruption has an eastward dispersal axis, consistent with the most common regional wind pattern. The first recognition of this eruption is found in the pioneering work by Salmi (1941).

We observed the Cha2 deposit on top of granitic outcrops less than $10 \mathrm{~km}$ east of Chaitén Volcano. There, it is composed of a coarse-grained yellow pumice layer $>1 \mathrm{~m}$ thick with maximum pumice clasts of about $10 \mathrm{~cm}$ and a median grain diameter $>6 \mathrm{~mm}$. Almost $85 \mathrm{~km}$ east of the volcano, in Argentina, the deposit is a few tens of $\mathrm{cm}$ thick but much finer grained, having maximum pumice clasts $<2 \mathrm{~cm}$ and a median grain diameter of about $2 \mathrm{~mm}$. We also identified this deposit along the road between Turbio Chico and Michinmahuida rivers (Fig. 1), where it rapidly decreases in both thickness and grain size southward (Table 4). All observed deposits displayed a characteristic reverse grading of pumice particles.

Watt et al. (2013, this volume) correlate the tephra layer Mic2 with a proximal pyroclastic sequence at Chaitén, which they called the Cha2 deposit and dated at $4.95 \mathrm{ka} \mathrm{BP}$. At the Mallines section (Fig. 2), a paleosol underneath a fall deposit that we correlate with Cha2 was dated at 5.4-5.1 ka BP, close to the previously proposed age. At the Gigios River, a few $\mathrm{km}$ north of the proximal site of Watt et al. (2013, this volume), we identified a several-meter-thick pyroclastic density current (PDC) deposit that contains pieces of the underlying soil. Two charcoal samples within that PDC deposit were dated at 5.3-4.9 ka BP. To the south, an undated pumice-block-bearing deposit found along the Chaitén River is correlated to Cha2 based on glass chemistry (see below). The thickness, distribution, and date of the Cha2 deposit indicate that a large and complex mid-Holocene eruption of Chaitén caused widespread regional effects.

Slightly contrasting dates for the Cha2 deposit were obtained on two soils beneath it at Turbio Chico, south of the Mallines section. There, paleosols underneath fall deposits were dated at 4.8-4.4 and 4.8-4.5 ka BP. In addition, Naranjo and Stern (2004) reported two (calibrated) ages from peats underneath the Mic2 (=Cha2) deposit in Argentina, of about 5.1 and $4.1 \mathrm{ka} \mathrm{BP}$. These different ages may indicate two large explosive events in the mid- to late-Holocene 
from an evolved source. We have not observed fall deposits from two large and closely spaced eruptions in any single section, even after a detailed inspection and sampling at the Mallines site.

Considering the thicknesses of the Cha2 (Mic2) deposit in tens of sections studied during our field campaigns and thicknesses reported by Naranjo and Stern (2004) around the Futalaufquén Lake and Esquel in Argentina, we have redrawn isopach contours (Fig. 4d) and estimated a tephra volume of $3 \mathrm{~km}^{3}$ for the Cha2 tephra fall. Watt et al. (2013, this volume) reported a tephra volume of $4.7 \mathrm{~km}^{3}$ for this deposit.

\subsection{Moderate- and minor-size events}

\subsubsection{Michinmahuida and pyroclastic cones}

At the Mallines section (Fig. 2), six scoria fall deposits were identified. Five of those deposits are likely from eruptions of Michinmahuida Volcano based on chemical signatures (Fig 3). Among them, the fourth (from top to bottom) scoria deposit $(15 \mathrm{~cm}$ thick) was correlated with the $\mathrm{Micl}$ deposit (Naranjo and Stern, 2004). The other scoria layers are all between 15 and $20 \mathrm{~cm}$ thick, coarse grained, and none of them has been reported previously. On the basis of stratigraphic position, scoria deposit 6 (Fig. 2) is older than Chal but younger than the Amarillo ignimbrite. Scoria deposit 5 lies between the Chal and Micl deposits. Scoria deposits 2 and 3 are younger than the Cha2 deposit. A paleosol between these two scoria layers is dated at 1.3-1.1 ka BP. Scoria deposit 1 is about $40 \mathrm{~cm}$ thick and composed of several layers that vary in thickness and grain size, but likely have similar compositions. This deposit resembles a strombolian deposit, which suggests it probably originated from one of the numerous young scoria cones that have erupted along the LOFZ and on the flanks of Michinmahuida Volcano. This youngest scoria deposit has also been observed along the Michinmahuida River valley. A paleosol on top this sequence of deposits in the Mallines section has a calibrated age within the last 300 years (Table 3).

Along the Turbio Chico and Michinmahuida River valleys, a dark scoria fall deposit lies beneath a white rhyolitic ash layer derived from a severalhundred-year-old eruption of Chaitén Volcano (discussed below). Those two deposits are separated by an undated paleosol. The mafic deposit is similar to the first scoria deposit described at the Mallines sec- tion. On the other hand, at a proximal section on the southern flank of Michinmahuida Volcano, the same white, fine ash layer is bracketed by two dark scoria fall deposits. Therefore, that stratigraphy suggests that the last eruptive activity in the region prior to 2008 was likely related to a scoria cone eruption. The vent related to that eruption is unknown, but scoria cones of young morphology are located along the LOFZ a few km south of Michinmahauida Volcano. On the southern flank of Michinmahuida Volcano two scoria fall deposits were identified. They are older than Micl but younger than the rhyolite fall between Chal and Cha2. Based on the limited spatial distribution and thickness, they are likely related to scoria cone eruptions.

A grey, dacitic lapilli-fall deposit has been observed along the Turbio Chico and Michinmahuida River valleys and on the upper southern flank of Michinmahuida Volcano, although it was not identified at the Mallines section. Lack of preservation at the Mallines section suggests that the tephra plume may have been transported in a mainly southeast direction. Samples from this lapilli-fall deposit plot within the dacite field (Fig. 3) and similar composition is obtained from glass analyses (Table 2). Therefore these samples represent the most evolved compositions known for Michinmahuida Volcano. That fall deposit likely accumulated during the last large explosive event at Michinmahuida. A paleosol beneath that deposit is dated between 500 and 300 years BP (Table 3 ). The number of sections measured containing the deposit is insufficient to estimate its volume. However, based on its thickness and grain size (Table 4), the event that produced this deposit may be larger than the 2008 Chaitén eruption but smaller than Micl. The youngest terrace along the Amarillo River, south of Michinmahuida Volcano, is composed mostly of material derived from this eruption. Sediment accumulation in that terrace indicates that substantial sediment aggradation occurred after the eruption. In summary, scoria and pumice deposits from small- to moderate-size eruptions (VEI 3-4) have been recognized mainly to the south and southeast of Michinmahuida Volcano. However, a weathered reddish scoria about $10 \mathrm{~cm}$ thick has been found west of Chaitén Volcano, near the locality of Santa Barbara. It is not clear yet to which eruption that scoria is correlated or if it is related to the scoria fall deposit reported on Chiloé Island by Heusser et al. (1995). 


\subsubsection{Chaitén}

In addition to deposits derived from large events, two additional sets of deposits derived from eruptions of Chaitén were observed in this study. A rhyolitic tephra deposit was recognized in two sections east of Chaitén Volcano. Pumices within this deposit have $<5$ vol. $\%$ of macroscopic ( $<1 \mathrm{~cm}$ long) biotite phenocrysts, which are different from the nearly aphyric white and yellow pumices previously associated with Chaitén. The age of this deposit is not well constrained, but it lies stratigraphically between the Cha1 (ca. $9.7 \mathrm{ka} \mathrm{BP}$ ) and Cha2 (ca. $5.0 \mathrm{ka} \mathrm{BP})$ deposits. Some discrepancy regarding its age arises, because a thick paleosol with evidence of reworking lies immediately above this deposit at the Mallines section (Fig. 2). The paleosol has an inverted age structure. It has been dated at 6.2-5.9 ka BP at its base and 7.6-7.3 ka BP at its top. As discussed earlier, Douglass et al. (2005) reported glacier advances and increased rainfall rates in northern Patagonia that peaked at $c a .8 .5$ and $6.2 \mathrm{ka}$ BP, respectively. Such changes in environmental conditions could have resulted in greater rates of reworking of sediment in the region. To our knowledge, no eruption of Chaitén Volcano between Chal and Cha2 has been previously confirmed. However, Watt et al. (2011a) reported one inconsistent age for a distinctive rhyolitic ash layer that they correlated with Chal in the Hualaihué region ( $c a .160 \mathrm{~km}$ north of Chaitén Volcano). That rhyolitic ash is deposited above a paleosol dated at 8.4-8.2 ka BP and is therefore younger than Chal. Acknowledging that this uncertainty comes from one sample at a single site, that stratigraphic discrepancy suggests the ash may be from a different event. On the other hand, Watt et al. (2013, this volume) indicated that glass compositions of obsidian clasts within the Cha2 deposit are comparable neither to Cha2 nor Chal juvenile pumices. They interpreted those obsidian clasts as older material cleared from the vent during the Cha 2 eruption, and noted that they may have originated from an unidentified volcanic event younger than Cha1. Glass compositions of pumice and ash from our uncorrelated rhyolite layer at Mallines section are similar to those reported for the unusual obsidian clasts by Watt et al. (2013, this volume).

A few-cm-thick, white, fine ash of rhyolitic composition was observed about 20 to $30 \mathrm{~km}$ southeast of Chaitén Volcano, along the Turbio Chico and Michinmahuida river valleys. This deposit is close to the current surface and likely corresponds to the last eruption of Chaitén Volcano prior to the 2008 event. It has been correlated to a $17^{\text {th }}$ century eruption mentioned in historical reports, which is now interpreted as an eruption of Chaitén (Lara et al., 2013, this volume). A soil directly on top of the ash layer indicates an age older than 300 years BP (Table 3). Preliminary isopachs for the fine ash deposit (not shown) suggest a bulk tephra volume of about $0.5 \mathrm{~km}^{3}$, which suggests an eruption similar in size to the 2008 eruption (Alfano et al., 2011; Major and Lara, 2013, this volume). This rhyolite ash deposit is fine grained, with about 30 vol. $\%$ of the deposit $<10 \mu \mathrm{m}$ and roughly $10-20$ vol. $\%<4 \mu \mathrm{m}$. Moreover, XRD analysis indicates the presence of cristobalite. Along the Chaitén River we observed pre-2008 lahar deposits that could be related to this event. Those deposits overlie a non-volcanic debris-flow deposit encasing tree trunks dated between 0.91-0.65 ka BP (Table 3). Watt et al. (2013, this volume) reported deposits from two small eruptive events younger than Cha2, which they called Cha3 and Cha4. However, neither detailed age control nor spatial distribution are presented, which makes it difficult to correlate either of those two deposits with the young deposit we observed.

\subsection{Glass chemistry}

In previous studies, fingerprinting of the of large eruptions usually has been done by characterizing whole-rock major and trace element contents of juvenile material in deposits. However, glass chemistry represents a more powerful tool for identifying sources and correlating units, particularly when whole-rock compositions are similar or when distal fall deposits are composed almost entirely of glass shards. In this study, glasses were collected from outcrops where the stratigraphy and eruption sources are well understood so that they can be linked to explosive events discussed above.

Glass compositions of the Chaitén samples are all rhyolitic, although subtle geochemical differences are observed within major element compositions (Fig. 5). These contrasts are highlighted when the data are grouped according to different time periods. In order to improve clarity, multiple glass analyses of the same sample are plotted as the average value \pm 1 standard deviation. The pumice erupted in May 2008 is compositionally indistinguishable from that of an eruption a few centuries earlier (Lara et al., 2013, 


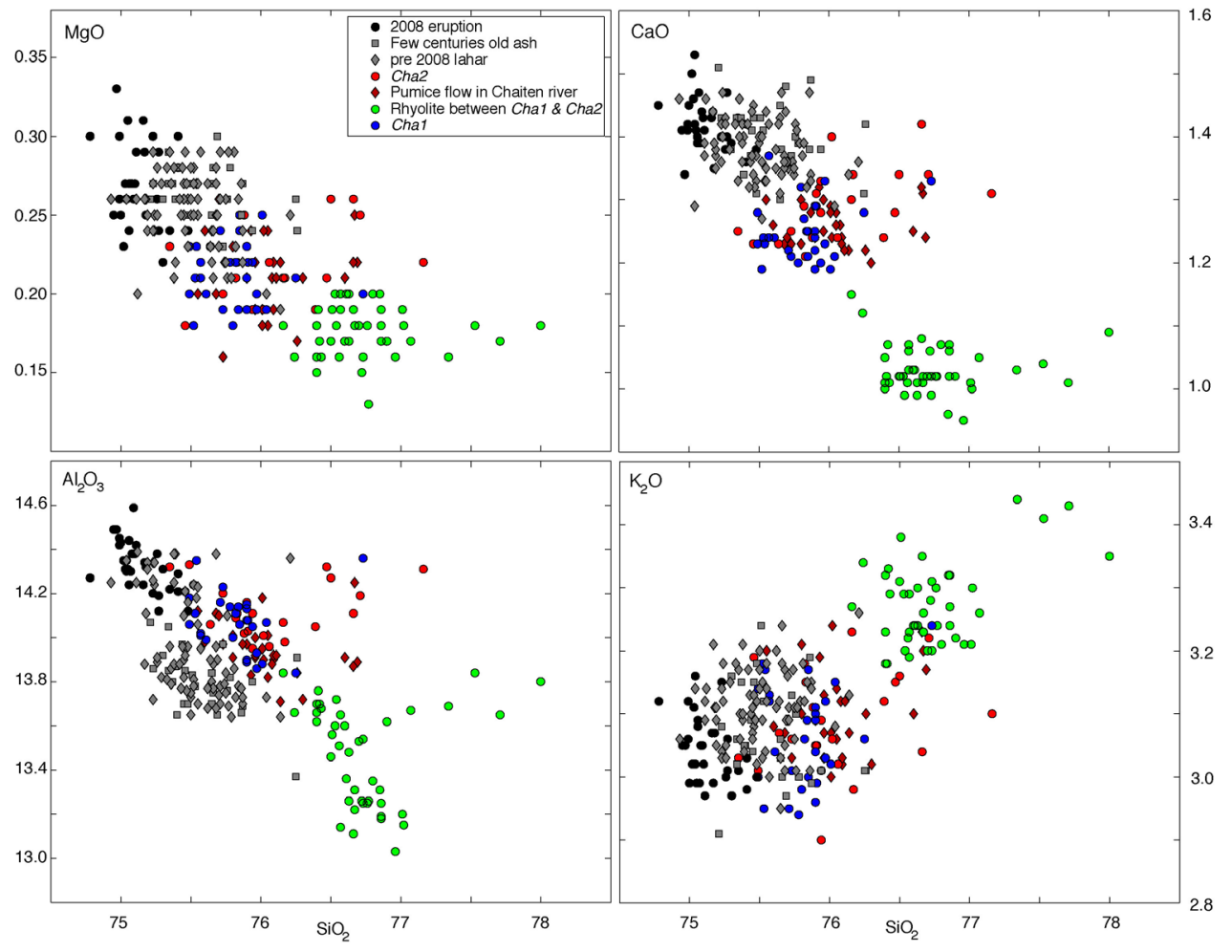

FIG. 5. Major element compositions of single analyses for Chaitén glass samples determined by electron microprobe in this study. All analyses were normalized to anhydrous compositions.

this volume), which is represented by the 'pre-2008 lahar' and the 'few centuries old ash' samples (Fig. 6). Compositions of deposits produced by eruptions of Chaitén Volcano over the last thousand years form a distinct group that differs from the composition of the Cha3 and Cha4 events of Watt et al. (2013, this volume). Samples of deposits having an inferred age similar to the Cha2 event ( $c a .5 \mathrm{ka}$ ), such as distal tephra in Argentina (Mic2), the proximal section of Watt et al. (2013, this volume), and the Cha2 fall deposit at the Mallines section, have glass chemistry similar to the pyroclasts of an undated pumice-and-block-bearing deposit observed along the Chaitén River valley (Fig. 6). That similarity suggests that those river valley deposits are from the same eruption, or from a phase of similar activity, from Chaitén about $5.0 \mathrm{ka} \mathrm{BP}$. The most evolved glass compositions from Chaitén, characterized by high $\mathrm{SiO}_{2}$ contents and low $\mathrm{MgO}$ and $\mathrm{CaO}$, are observed in the uncorrelated rhyolite layer (between Cha1 and Cha2) at the Mallines section, which is dated older than $7.6 \mathrm{ka}$. The compositions of the glass shards in that deposit are similar to preCha 2 obsidian clasts reported by Watt et al. (2013, this volume), suggesting that they are products from the same eruption (Fig. 6). Finally, the oldest known rhyolite unit (Cha1; ca. $9.7 \mathrm{ka}$ ) reported by Watt et al. (2013, this volume), has a glass composition similar to the Chal fall deposit at the Mallines section, suggesting that they are correlated (Fig. 6).

\section{Conclusions}

New field and analytical data presented in this study indicate that Chaitén and Michinmahuida Volcanoes are much more active than previously reported, and they show a wide range of explosive activity. Volcanic hazards derived from these volcanoes are related mostly to lahars along the main river valleys draining the volcanoes, and to tephra falls.

Recent activity (within the past 1,000 years) has been dominated by small- to moderate-size eruptions. In the 500 years prior to the 2008 eruption of Chaitén 


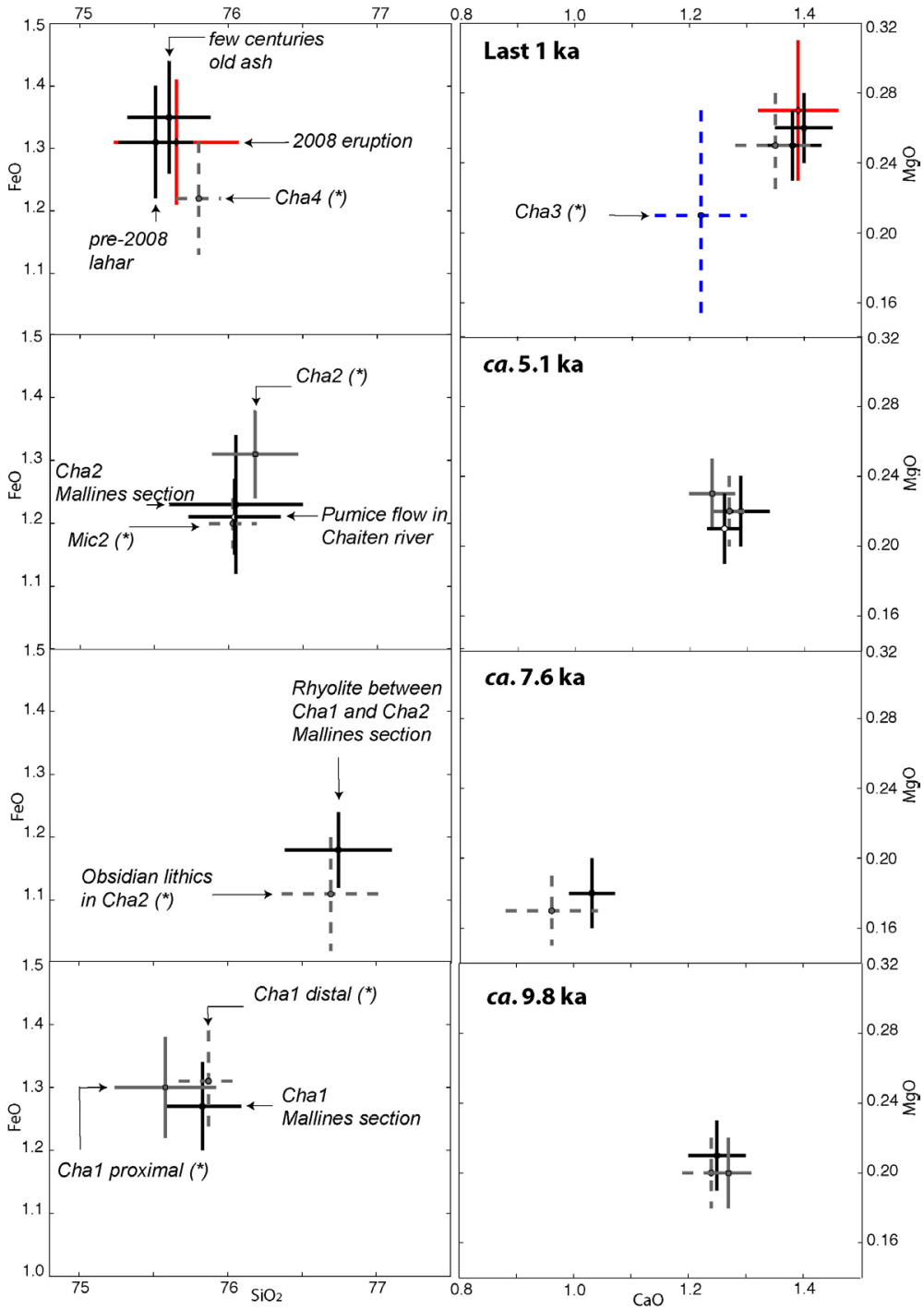

FIG. 6. Major element compositions for Chaitén glass samples determined by electron microprobe. The data are grouped according to age and plotted as an average value \pm 1 standard deviation. Red color indicates 2008 glass data (including Watt et al., 2009, Alfano et al., 2011, and Lowenstern et al., 2012). Grey and blue color indicate data from Watt et al. (2013, this volume), also marked as $(*)$. All analyses were normalized to anhydrous compositions.

there was: 1. a small scoria-cone eruption from the upper southern flank of Michinmahuida Volcano; 2. an explosive eruption from Chaitén Volcano similar in size to the 2008 event, which deposited pyroclastic material up to $20-30 \mathrm{~km}$ to the southeast of the volcano and triggered lahars along the Chaitén River; 3. a regional scoria-cone eruption having several eruption pulses, and 4. a moderate-size (VEI 3-4) explosive eruption from Michinmahuida Volcano characterized by fall deposits containing grey dacite pumice. That eruption of Michinmahuida appears to have triggered lahars along the Amarillo River. The dacitic pyroclasts in products of this eruption represent the most evolved composition known from Michinmahuida Volcano.

Products from five moderate-size (VEI 4-5) Holocene eruptions were identified from Michinmahuida Volcano. One of the deposits (Mic 1) was identified in distal regions to the east. Another uncorrelated fall deposit was found to the west. In addition, a large 
(VEI $>5$ ) ignimbrite-forming eruption occurred in the early Holocene and produced a non-welded andesitic ignimbrite (the Amarillo ignimbrite) that was emplaced along the main valleys around the volcano.

Recent studies have shown that Chaitén Volcano had multiple large eruptions (VEI 5) prior to the 2008 event, namely the Cha 1 and Cha 2 events. These eruptions are among the largest explosive events in the southernmost SVZ during the Holocene. In addition to the deposits from these eruptions, products from two smaller Holocene eruptions were identified: 1. a deposit from an explosive event that occurred between the Cha1 and Cha2 events (presumably older than $7.6 \mathrm{ka} \mathrm{BP}$ ) is the most compositionally evolved product of any eruption of Chaitén; and 2. deposits from a few-centuries-old eruption that appears to have been similar in size to the 2008 event. Even though whole-rock compositions are remarkably similar for products derived from Chaitén Volcano, glass analyses indicate subtle differences that help distinguish and correlate the deposits.

Proximal studies at large remote volcanoes in southern Chile are needed to better assess the eruptive history and hazards in this part of Chile. Rigorous analyses of glass compositions from volcanoes are needed to help better identify source eruptions for the eruptive deposits that are scattered broadly across southern Chile and Argentina.

\section{Acknowledgments}

D. Bertin helped to estimate noncompacted volumes presented in this study. C. Troncoso drew an initial version of the stratigraphic column for the Mallines section. G. Orozco and C. Ramos participated in several field campaigns under difficult conditions. We thank S. Watt and J. Lowenstern for sharing microprobe data. The ODP team is acknowledged for sending one ash sample from the 1233 site. Reviews from S. Watt, J. Lowenstern and J. J. Major are highly appreciated and improved this paper substantially. This is a contribution to the Programa de Riesgo Volcánico at SERNAGEOMIN.

\section{References}

Abarzúa, A.M.; Villagrán, C.; Moreno, P.I. 2005. Deglacial and postglacial climate history in east-central Isla Grande de Chiloé, southern Chile $\left(43^{\circ} \mathrm{S}\right)$. Quaternary Research 62: 49-59.

Alfano, F.; Bonadonna, C.; Volentik, A.C.M.; Connor, C.B.; Watt, S.F.L.; Pyle, D.M.; Connor, L.J. 2011.
Tephra stratigraphy and eruptive volume of the May, 2008 Chaitén eruption. Chile. Bulletin of Volcanology 73: 613-630.

Bonadonna, C.; Costa, A. 2012. Estimating the volume of tephra deposits: a new simple strategy. Geology 40: 415-418.

Bronk Ramsey, C. 2009. Bayesian analysis of radiocarbon dates. Radiocarbon 51: 337-360.

Carn, S.A.; Pallister, J.S.; Lara, L.E.; Ewert, J.W.; Watt, S.; Prata, A.J.; Thomas, R.J.; Villarosa, G. 2009. The Unexpected Awakening of Chaitén Volcano, Chile. Eos, Transactions of the American Geophysical Union 90 (24): 205-206.

Darwin, C.R. 1840. On the connexion of certain volcanic phenomena in South America; and on the formation of mountain chains and volcanos, as the effect of the same power by which continents are elevated. Transactions of the Geological Society of London 5: 601-631.

Denton, G.H.; Heusser, C.J.; Lowell, T.V.; Moreno, P.I.; Andersen, B.G.; Heusser, L.E.; Schlucter, C.; Marchant, D.R. 1999. Interhemispheric linkage of paleoclimate during the Last Glaciation. Geografiska Annaler, Series A, Physical Geography 81 (2): 107-153.

D’Orazio, M.; Innocenti, F.; Manetti, P. 2003. The Quaternary calc-alkaline volcanism of the Patagonian Andes close to the Chile triple junction: geochemistry and petrogenesis of volcanic rocks from the Cay and Maca volcanoes $\left(45^{\circ} \mathrm{S}\right.$, Chile). Journal of South American Earth Sciences 16 (4): 219-242.

Douglass, D.C.; Singer, B.S.; Kaplan, M.R.; Ackert, R.P.; Mickelson, D.M.; Caffee, M.W. 2005. Evidence of early Holocene glacial advances in southern South America from cosmogenic surface-exposure dating. Geology 33 (3): 237-240.

Farr, T.G.; Rosen, P.A.; Caro, E.; Crippen, R.; Duren, R.; Hensley, S.; Kobrick, M.; Paller, M.; Rodríguez, E.; Roth, L.; Seal, D.; Schaffer, S.; Shimada, J.; Umland, J.; Werner, M.; Oskin, M.; Burbank, D.; Alsdorf, D. 2007. The Shuttle Radar Topography Mission. Reviews of Geophysics 45 (RG2004). doi:10.1029/ 2005RG000183.

Folch, A.; Jorba, O.; Viramonte, J.G. 2008. Volcanic ash forecast: application to the May 2008 Chaitén eruption. Natural Hazards and Earth Systems Science 8 (4): 927-940.

Garreaud, R.D. 2009. The Andes climate and weather. Advances in Geosciences 7: 1-9.

Hajdas, I.; Bonani, G.; Moreno, P.I.; Ariztegui, D. 2003. Precise radiocarbon dating of Late-Glacial cooling 
in mid-latitude South America. Quaternary Research 59: 70-78.

Hastie, A. R.; Kerr, A. C.; Pearce, J. A.; Mitchell, S. F. 2007. Classification of altered volcanic island arc rocks using immobile trace elements: Development of the Th - Co discrimination diagram. Journal of Petrology 48: 2341-2357.

Heusser, C.J.; Heusser, L.E.; Hauser, A. 1992. Paleoecology of late Quaternary deposits in Chiloé continental, Chile. Revista Chilena de Historia Natural 65: 235-245.

Heusser, C.J.; Denton, G.H.; Hauser, A.; Andersen, B.G.; Lowell, T.V. 1995. Quaternary pollen records from the Archipiélago de Chiloé in the context of glaciations and climate. Revista Geológica de Chile 22 (1): 25-46.

Horwell, C.J. 2007. Grain-size analysis of volcanic ash for the rapid assessment of respiratory health hazard. Journal of Environmental Monitoring 9: 1107-1115.

Jochum, K.P.; Stoll, B.; Herwig, K.; Willbold, M.; Hofmann, A.W.; Amini, M.; Aarburg, S.; Abouchami, W.; Hellebrand, E.; Mocek, B.; Raczek, I.; Stracke, A.; Alard, O.; Bouman, C.; Becker, S.; Dücking, M.; Brätz, H.; Klemd, R.; de Bruin, D.; Canil, D.; Cornell, D.; de Hoog, C.; Dalpé, C.; Danyushevsky, L.; Eisenhauer, A.; Gao, Y.; Snow, J.E.; Groschopf, N.; Günther, D.; Latkoczy, C.; Guillong, M.; Hauri, E.; Höfer, H.E.; Lahaye, Y.; Horz, K.; Jacob, D.E.; Kasemann, S.A.; Kent, A.J.R.; Ludwig, T.; Zack, T.; Mason, P.R.D.; Meixner, A.; Rosner, M.; Misawa, K.; Nash, B.P.; Pfänder, J.; Premo, W.R.; Sun, W.D.; Tiepolo, M.; Vannucci, R.; Vennemann, T.; Wayne, D.; Woodhead, J.D. 2006. MPI-DING reference glasses for in situ microanalysis: new reference values for element concentrations and isotope ratios. Geochemistry, Geophysics, Geosystems 7 (Q02008). doi: 10.1029/2005GC001060.

Kilian, R.; López-Escobar, L. 1992. Petrology of the Southern Southandean Volcanic Zone $\left(41-46^{\circ} \mathrm{S}\right)$ with emphasis on the Michinmahuida-Chaitén complex $\left(43^{\circ} \mathrm{S}\right)$. Zentralblatt für Geologie und Paläontologie Teil 11991 (6): 1693-1708.

Lamy, F.; Kaiser, J. 2009. Glacial to Holocene Paleoceanographic and Continental Paleoclimate Reconstructios Based on ODP site 1233/GeoB 3313 Off Southern Chile. In Past Climate Variability in South America and Surrounding Regions (Vimeux, F.; Sylvestre, F.; Khodri, M.; editors). Developments in Paleoenvironmental Research 14: 129-156.

Lara, L.E.; Amigo, Á.; Moreno, H. 2009. Volcanismo explosivo del volcán Michinmahuida: primeros antecedentes de una ignimbrita postglacial. In Con- greso Geológico Chileno, No. 12, CD Rom: S07-15. Santiago.

Lara, L.E.; Moreno, R.; Amigo, Á.; Hoblitt, R.P.; Pierson, T.C. 2013. Late Holocene history of Chaitén Volcano: New evidence for a $17^{\text {th }}$ century eruption. Andean Geology 40 (2): 249-261.

López-Escobar, L.; Kilian, R.; Kempton, P.; Tagiri, M. 1993. Petrography and geochemistry of Quaternary rocks from the Southern Volcanic Zone of the Andes between $41^{\circ} 30^{\prime}$ and $46^{\circ} 00^{\prime} \mathrm{S}$, Chile. Revista Geológica de Chile 20 (1): 33-55.

Lowenstern, J.B.; Bleick, H.; Vásquez, J.; Castro, J.M.; Larson, P.B. 2012. Degassing of Cl, F, Li, and Be during extrusion and crystallization of the rhyolite dome at Volcán Chaitén, Chile. Bulletin of Volcanology 74 (10): 2303-2319.

Major, J.J.; Lara, L.E. 2013. Overview of Chaitén Volcano, Chile, and its 2008-2009 eruption. Andean Geology 40 (2): 196-215.

McCormac, F.G.; Hogg, A.G.; Blackwell, P.G.; Buck, C.E.; Higham, T.F.G.; Reimer, P.J. 2004. SHCal04 Southern Hemisphere calibration, 0-11 cal kyr BP. Radiocarbon 46 (3): 1087-1092.

Moreno, P.I.; Jacobson, G.L.; Andersen, B.G.; Lowell, T.V.; Denton, G.H. 1999. Abrupt vegetation and climate changes during the last glacial maximum and the last Termination in the Chilean Lake District: a case study from Canal de la Puntilla (41 $\left.{ }^{\circ} \mathrm{S}\right)$. Geografiska Annaler Series A-Physical Geography 81 (2): 285-311.

Moreno, P.I. 2004. Millennial-scale climate variability in Northwest Patagonia over the last 15000 yr. Journal of Quaternary Science 19 (1): 35-47.

Naranjo, J.A.; Stern, C.R. 2004. Holocene tephrochronology of the southernmost part $\left(42^{\circ} 30^{\prime}-45^{\circ} \mathrm{S}\right)$ of the Andean Southern Volcanic Zone. Revista Geológica de Chile 31 (2): 225-240.

Osores, M.S.; Folch, A.; Collini, E.; Villarosa, G.; Durant, A.; Pujol, G.; Viramonte, J.G. 2013. Validation of the FALL3D model for the 2008 Chaitén eruption using field and satellite data. Andean Geology 40 (2): 262-276.

Pallister, J.P.; Diefenbach, A.K.; Burton, W.C.; Munoz, J.; Griswold, J.P.; Lara, L.E.; Lowenstern, J.B.; Valenzuela, C.E. 2013. The Chaitén rhyolite lava dome: Eruption sequence, lava dome volumes, rapid effusion rates and source of rhyolite magma. Andean Geology 40 (2): 277-294.

Pearce, J. A. 1996. A user's guide to basalt discrimination diagrams. In Trace Element Geochemistry of Volcanic Rocks: Applications for Massive Sulphide Explora- 
tion (Wyman, D. A.; editor). Geological Association of Canada, Short Course Notes 12: 79-113.

Piña-Gauthier, M.; Lara, L.E.; Bataille, K.; Tassara, A.; Baez, J.C. 2013. Co-eruptive deformation and dome growth during the 2008-2009 Chaitén eruption, Southern Andes. Andean Geology 40 (2): 310-323.

Porter, S.C. 2000. Onset of neoglaciation in the Southern Hemisphere. Journal of Quaternary Science 15 (4): 395-408.

Salmi, M. 1941. Die postglazialen eruptions schichten Patagoniens und Feuerlands. Annales Academiæ Scientiarum. Fennicae, series A III (2): 1-115.

Sarna-Wojcicki, A.M.; Shipley, S.; Waitt Jr., R.B.; Dzurisin, D.; Wood, S.H. 1981. Areal distribution, thickness, mass, volume, and grain size of air-fall ash from the six major eruptions of 1980. In The 1980 eruptions of Mount St. Helens (Lipman, P.W.; Mullineaux, D.R; editors). United States Geological Survey, Professional Paper 1250: 577-600.

Scasso, R.A.; Corbella, H.; Tiberi, P. 1994. Sedimentological analysis of the tephra from the 12-15 August 1991 eruption of Hudson Volcano. Bulletin of Volcanology 56 (2): 121-132.

Stern, C.R.; Kilian, R. 1996. Role of the subducted slab, mantle wedge and continental crust in the generation of adakite from the Andean Austral Volcanic Zone. Contributions to Mineralogy and Petrology 123: 263-281.
Stern, C.R. 2004. Active Andean volcanism: its geologic and tectonic setting. Revista Geológica de Chile 31 (2): 161-206.

Villarosa, G.; Outes, V.; Hajduk, A.; Sellés, D.; Fernández, M.; Crivelli Montero, E.; Crivelli, E. 2006. Explosive volcanism during the Holocene in the upper Limay river basin: The effects of ashfalls on human societies. Northern Patagonia, Argentina. Quaternary International 158 (1): 44-57.

Watt, S.F.L.; Pyle, D.M.; Mather, T.A.; Martin, R.S.; Matthews, N.E. 2009. Fallout and distribution of volcanic ash over Argentina following the May 2008 explosive eruption of Chaitén, Chile. Journal of Geophysical Research 114 (B04207). doi: 10.1029/ 2008JB006219.

Watt, S.F.L.; Pyle, D.M.; Mather, T.A. 2013. Evidence of mid- to late-Holocene explosive rhyolitic eruptions from Chaitén Volcano, Chile. Andean Geology 40 (2): 216-226.

Watt, S.F.L.; Pyle, D.M.; Naranjo, J.A.; Rosqvist, G.; Mella, M.; Mather, T.A.; Moreno, H. 2011a. Holocene tephrochronology of the Hualaihue region (Andean southern volcanic zone, $\left.\sim 42^{\circ} \mathrm{S}\right)$, southern Chile. Quaternary International 246 (1-2): 324-343.

Watt, S.F.L.; Pyle, D.M.; Mather, T.A. 2011b. Geology, petrology and geochemistry of the dome complex of Huequi Volcano, southern Chile. Andean Geology 38 (2): 335-348.

Manuscript received: February 05, 2013; revised/accepted: April 19, 2013; available online: April 19, 2013. 